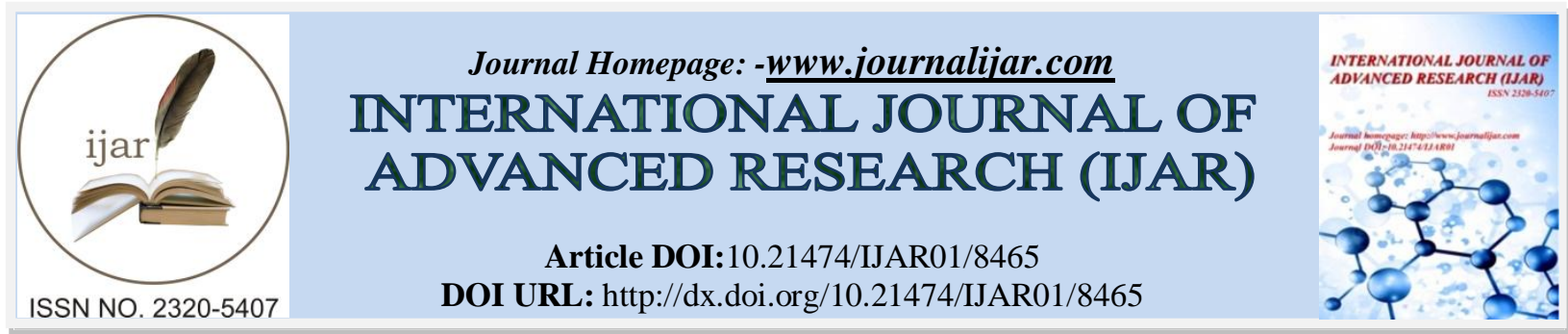

RESEARCH ARTICLE

\title{
THE BUOYANCY OF THE VALUE ADDED TAX ON ECONOMIC DEVELOPMENT: ITS DRIFTS AND CHALLENGES IN CAMEROON.
}

\section{Akama Samuel Penda ${ }^{1}$ andBandeGulbertMbahTarh ${ }^{2}$.}

1. Ph.D. in Law, Senior Lecturer, Head of Department of English Law, FSJP, University of Maroua.

2. Ph.D. in Law, Lecturer, FSJP, University of Maroua.

\section{Manuscript Info}

\section{Manuscript History}

Received: 02 December 2018

Final Accepted: 04 January 2019

Published: February 2019

\section{Key words:-}

Buoyancy, Value Added Tax, Economic

Development, Challenges and

Cameroon.

\begin{abstract}
Value Added Tax (VAT) is essentially the tax charged on a wide range of transactions, with a mechanism to offset the tax paid on inputs against those paid on outputs thereby enhancing its buoyancy and efficiency on economic development. As well, VAT expediently exhibits considerable diversity as regards, inter alia, the base of the tax and the range of economic activity to which the tax applies. Consequently, there can be room for disagreement as to whether a given tax is properly called a VAT or not. This paper, therefore, tries to assess and provide an understanding of VAT as a tax initially developed to meet the rising revenue requirements that could not easily be satisfied by the existing turnover taxes and the cascading nature which could seriously distort economic decisions. In this connection, the paper, thus, applauds the significance of the adoption of the VAT system in Cameroon - introduced first in its tax reform system in the $1990 \mathrm{~s}$ - as an integral part of the adjustment policies engaged in the second half of the 1980s; to form the focal point in enhancing the economic development of Cameroon. Correspondingly, it accentuates the importance of the informal sector which was not taken into account in the new fiscal scheme. By so doing, it extends the methodological framework used in the analysis of optimal taxation to both formal and informal sectors. In fact, based on an earlier data from the Cameroonian survey on household consumption and the Directorate General of Taxation, it finds that in the informal sector some goods and services like clothing, tobacco, drinks, health and agriculture are currently unduly exonerated from VAT and however suggests that they should be included and taxed. The paper, in a nutshell, provides the drifts and challenges of VAT, and proffers the necessary recommendation for a buoyant and viable VAT system in Cameroon.
\end{abstract}

Copy Right, IJAR, 2019. All rights reserved.

Corresponding Author:-Akama Samuel Penda.

Address:- Ph.D. in Law, Senior Lecturer, Head of Department of English Law, FSJP, University of Maroua. 


\section{Introduction:-}

Explicitly, Value Added Taxes (VAT) is "a general tax on consumption (becoming payableevery time an article of merchandise or service is supplied), in multi-phase form, because it is paid at all points on the economic circuit without cumulative effects" ". This type of taxes is one of the most successful in the "world of taxation" and the most important development in taxation in the last century. ${ }^{2}$ It was invented in 1954 by Maurice Lauré, the joint director of French tax authorities ${ }^{3}$, and implemented in France in that year, through the Decree-Law n ${ }^{\circ}$ 394-B/84, of 26 December. Even though the German industrialist Wilhelm vonSiemens had earlier proposed the concept in $1918 .{ }^{4}$ Likewise, VAT was first expediently suggested in Germany during the post-First World War period as a replacement for the country's turnover tax which was similar to the VAT system but did not provide rebates for the taxes paid at each stage. By the same token, other proponents of VAT suggested that the United States adopted it as a substitute for excise taxes imposed after the War. In spite of this, it is worth noting that it was only in 1953 that the VAT system was formally put in place in the United States or Europe. In that same year, Michigan adopted a modified VAT system, termed a Business Activities Tax, which it used for 14 years. As aforementioned, France was the first country to use VAT to partially replace its own turnover tax system, by applying the GNP-based VAT, covering the manufacturing level and subsequently replacing it with a consumption-based VAT in $1954 .{ }^{5}$ Equally, in 1967, the Council of European Economic Community (EEC) issued directives for the widespread adoption of VAT to replace the existing turnover taxes and link EEC members with a common tax system; with the hoped that the new system would increase foreign trade, already hindered by the complex regulatory practices of the turnover tax system. Indeed, after the directive, countries outside the EEC such as Austria, Sweden, Brazil, Greece, and Peru also adopted some variation of VAT, either in addition to or as a replacement for their own national tax structures. ${ }^{6}$

Compendiously, VAT was initially directed at large businesses, but subsequently extended over time to include all business sectors. ${ }^{7}$ Since it was realised that for VAT to be efficient intheory and practice, it must be consumptiontyped, broad-based, and applied through to the retail stage. Likewise, empirical studies have shown the interlinks between the VAT performance of a country and its level of development. With the revenue gains from VAT being likely to be higher in an economy with higher level of per capita income, lower share of agriculture, and higher level of literacy. ${ }^{8}$ Similarly, VAT has proved to be an efficient tool for revenue collection; its performance has direct impact on fiscal mobilization, macroeconomic stability, and development. Generally, VAT has more revenue potentials in comparison with the other alternatives of indirect taxation, as it is more broad-based and entails a trail of invoices that helps improve tax compliance and enforcement. Equally, VAT may eliminate the cascading problem, which is typical for the turnover tax. In this connection, Heady stresses that "VAT has become the sales tax of choice in OECD countries" with a clear, consistent and greater trend for the collection of sales tax revenues among OECD countries. ${ }^{9}$ Besides, it is worthwhile stressing that while these countries continue to rely heavily on income tax collection, VAT revenues have risen steadily in both absolute and relative terms; with the general consumption taxes having increased sharply from 12 percent of the total tax revenues in 1965 to 18 percent in $2000 .{ }^{10}$ Aptly, it is realised that a similar trend is applied to developing countries, which typically rely more on sales tax than OECD countries. In this regard, the IMF has assessed the growing importance and worldwide expansion of

\footnotetext{
${ }^{1}$ Palma-Celorico, C. (2008). "IntroduçãoaoImpostoSobreo Valor Acrescentado", N ${ }^{\circ} 1$ - $3^{\text {a }}$ Edição, p. 19.

${ }^{2}$ CosteiraBorralho, J-P. (2014). Tax Efficient Supply Chain. Master of Science in Business Administration Dissertation, ISCTE Business School, Department of Marketing and Logistics, September.

3 'Direction Générale des Impôts'

${ }^{4}$ Rehana, I. (2017). Value Added tax (VAT) - in View of Bangladesh, IOSR Journal of Business and Management, 10.9790/487X-1901060818.

${ }^{5}$ Hooper, P., and Karen, A. (1997). "A Value-Added Tax in the U.S.: An Argument in Favor." Business Horizons, May-June.

${ }^{6}$ Ogley, A. (1998). Principles of Value-Added Tax: A European Perspective. International Information Services, Inc ${ }^{7}$ Ebrill, L., et al. (2002). "The Allure of the Value-Added Tax."Finance and Development, June.

${ }^{8}$ One should caution, however, that the IMF study also indicates significant negative impact of the interactive VAT and trade liberalization on the revenue collection: the introduction of VAT, which replaces trade taxes during the course of trade liberalization, is likely to reduce the overall tax revenues. The results imply that the VAT may not be as effective as trade taxes in raising revenues. Ebrill et al. (2001).The Modern VAT. Washington D.C. IMF.

${ }^{9}$ Heady, C. (2002). "Tax Policy in Developing Countries: What Can Be Learned from OCED Experience?" Paper presented at the seminar "Taxing Perspectives: A Democratic Approach to Public Finance in Developing Countries," at the Institute of Development Studies, University of Sussex on 28-29 October. p. 4.

${ }^{10}$ Ibid., p.16.
} 
VAT and states that "VAT has become a key source of government revenue in over 120 countries; with about 4 billion people, 70 percent of the world's population, now living in countries with a VAT, and it raises about \$18 trillion in tax revenue-roughly one-quarter of all government revenue; with much of the spread of VAT having taken place over the last ten years; from having been largely the preserve of more developed countries in Europe and Latin America, has now become a pivotal component of the tax systems of both developing and transition economies". "In this perspective, the paper, thus, assess the following issues: primarily, it peruses the conceptual framework of VAT, its mechanism, design, implementation, policy implications, and distributional impact, and secondly, it elaborates on the drifts and challenges of VAT in Cameroon, especially after its introduction in $1999^{12}$. It then concludes by providing some recommendations that will aid in enhancing the buoyancy and efficiency of the VAT system in Cameroon.

\section{Conceptual Framework of the Value Added Tax}

Unequivocally, fiscal policy is that part of government policy measures concerned with the raising of revenue through taxation and other means; and deciding on the level and pattern of expenditure for the purpose of influencing economic activities or attaining some desired economic goals. ${ }^{13}$ Apropos, the taxes can be direct or indirect - with VAT being a form of indirect tax collected at various stages of the production-distribution chains. Indeed, if properly designed and implemented, the tax, at any stage, is effectively collected on the pure value added generated at that stage; as such, VAT can be viewed as equivalent to the single retail sales stage tax but implemented in a different fashion. In this regard, it is worth discussing further the mechanism and some good rationales for the VAT system. Besides, it should be noted that many developing countries have introduced VAT to replace the turnover tax or some type of single-stage sales tax, because they are considered to be inherently troublesome in terms of either revenue leakage or economic inefficiency or both. Aptly, to illustrate the relative advantages of VAT, in what follows, it is appropriate to briefly provide a review of the problems of the turnover and single-stage taxation. On the one hand, the "Turnover taxation"l4 is the tax imposed on every stage of the production-distribution chain, with the tax base at any single stage including the sales value of the goods plus the tax charged accumulatively in previous stages. In fact, the most serious problem with this tax is the "cascading effect", which is literally understood as the tax-on-tax effect - since the tax generates a trail of accumulated distortions carried from the first stage of production on to the last stage of retail, sales and distribution. Consequently, to gauge how bad the cascading effect is, one may simply imagine a situation, in which a smart entrepreneur negotiates with his partners to vertically integrate, and by colluding, they can avoid a large part of the tax burden.

On the other hand, the 'Single-stage taxation" 15 is the tax that can be imposed at any single stage of the productiondistribution chain - there may be manufacturing, wholesale, or retail sales taxation. The tax, at first glance, is

\footnotetext{
${ }^{11}$ Ebrill et al. (2001)., op cit. p. xi.

${ }^{12}$ See Finance Law No 98/009 of 1st July 1998 as implemented from 1st January 1999 and the General Tax code.

${ }^{13}$ Anyanwu, J. and Oaikhenan, B. (1995).Modern Macroeconomics Theory and Application in Nigeria.Department of Economics \& Statistics, University of Benin, Benin City.

${ }^{14}$ Turnover tax is a lump sum direct tax collected by Governments. It is worked out by just applying to a taxable turnover a single tax rate (see McCluskey, W. (2012). Land Value Taxation: An Applied Analysis. www.books.google.com), as opposed to income tax system that incorporate use of comprehensive rules and procedure that require maintenance of proof on every expenditure. Countries that apply turnover tax use different parameters to determine when the tax need to be assessed. The structure of a turnover tax varies with governments and types of goods taxed. This is intended to keep it affordable for everyone (see Cheeseman, N. and Griffiths, R. (2005). Increasing Tax Revenue in Sub-Saharan Africa: The Case of Kenya.Oxford Council on Good Governance, Economy Analysis, 6). Equally, tax payers are required to observe and comply with the turnover tax obligations of their country. Key compliance items are declaring income, filing a return and timely paying the tax when due (see McCluskey (2012).,op cit). Failure to comply with the tax obligations poses a serious challenge to tax authorities as it diminishes the mobilization of resources that governments need to invest in critical areas of social-economic development including health, education and infrastructure development (see Cummings, R. (2007). Effects of Tax Morale on Tax Compliance. Experimental and Survey Evidence, International Journal of Business and Management, 9(2), pp. 8-12).

${ }^{15}$ The single-stage taxation is implemented in China (with the name of Business Tax - BT -) and in the UnitedStates, where each state applies their own consumption taxes, most of which are single-stage taxes on the sale of goods. This system is characterized by the fact that it can be implemented at any stage of the economic circuit, including production, importation, distribution and retail sales. Since single-stage taxes may apply at multiple
} 
ideal,because its design is expected to eliminate the cascading effect and does not require huge administration costs (the base is significantly smaller than the one with the turnover tax). Besides, it has many potential problems, for instance, the tax at the manufacturing level needs "ring fencing"; the production of capital goods in order to avoid any bias against capital and the escalation of production costs. But however, it requires efficient monitoring to detect any potential reselling problem - ring-fenced firms may obtain their tax-free inputs, resell them to the market, and thereby erode the base. Likewise, the tax on wholesales stage is not easy to administer: the problem derives mainly from the obscure definition of the wholesale stage. For both manufacturing and wholesale stage taxation, the base is narrow, and hence the rates need to be high to collect sufficient revenues. Nonetheless, higher rates provide stronger incentives for evasion and avoidance; taxpayers can easily avoid the taxes by artificially lowering price at the taxed level (manufacturing or wholesale level) and raising price at the subsequent, untaxed level.

Conversely, as a matter of fact, the retail sales tax (which is currently applied, for example, at the state level in the U.S.) requires, inter alia, massive registration. In this regard, Mikesell ${ }^{16}$, in his brief on the topic entitled 'Retail Sales $\operatorname{Tax}{ }^{117}$, indicates that to ensure the economic efficiency of a retail sales tax regime, two major principles must be followed. First, the tax must be applied to all sales for final consumption at a uniform rate. Second, there must be no tax on savings or production consumption. However, it is realised that both conditions are practically hard to be met. It is not uncommon that tax regimes - applied in practice - feature multiple rates and exemptions. Equally, it is costly and administratively, to distinguish consumption (to be taxed) from production purchases (to be exempted) since there are many items used for both production and final consumption. Indeed, the administration of the retail sales tax is not simple for at least two reasons: (1) the tax requires that all retailers be registered to collect taxes from their customers; and (2) multiple exemptions and rates, and limited coverage (the tax is typically extended only to goods and very few services) tend to erode the base and give rise to the need for setting high standard rate for sufficient revenue collection. The high rate, however, would become an attractive invitation to evasion and avoidance. An interesting vicious circle can be seen: narrow base - high standard rate - evasion and avoidancenarrower base etc. In addition, retailers in developing countries are largely small, informal, and mobile (no fixed business location); these typical taxpayer characteristics combined with the complex tax regime pose real challenge to tax administration. In general, the single-stage sales taxation is prone to serious revenue leakage. By the same token, the tax collection is restricted to only one stage of the chain: if some businesses succeed in slipping out of the tax net (that is, at the tax point), revenues will immediately drop.

In a nutshell, it is worth noting that VAT is relatively more advantageous than the alternatives - be it turnover tax or single-stage tax - for the following reasons: First, it is generally more broad-based (as it is extended to cover both goods and services); second, it is less risky in terms of revenue leakage (as the invoice-based credit mechanism in administering VAT facilitates collection and enforcement; even if revenues are missed in one stage, they are still collected in other stages). Aptly, VAT, thus, has greater revenue potential than its alternatives. Even though opponents to VAT usually argue that VAT is more complex to administer than the other types of consumption taxation, and that the complexity naturally leads to higher collection costs (defined as the combined compliance costs from the taxpayer side, and the administration costs from the tax authority side). In addition, as discussed above, the taxes replaced by VAT in developing countries are generally far from being simple in their design and riddled with narrow base, multiple rates, and numerous exemptions. For instance, Philippines introduces VAT in 1988, replacing a web of indirect taxes including manufacturer's sales tax, turnover tax, advance sales tax on imports, miller's tax, forest charges, and other sorts of ad valorem taxes on services. In this regard, McMoran indicates that the administration and compliance costs under a single-stage tax and a VAT, extended to the same level in the production-distribution chain do not differ significantly. ${ }^{18}$

\section{Value Added Tax as a Self-enforcing and Buoyant $\operatorname{Tax}^{19}$}

Essentially, VAT is, in principle, described as "self-enforcing". This description stems from the nature of the invoice-based credit VAT: A taxable business can claim for the refund of the input VAT only if the claim is

stages, it can create a cascading effect (as taxes paid at an earlier stage from part of the taxable base) that leads to very high effective rates (see Palma-Celorico, C. (2008).,op cit., 18.)

${ }^{16}$ Mikesell, J. "Retail Sales Tax." Paper available at: http://www1.worldbank.org/publicsector/tax/retailtax.htm

${ }^{17}$ The topic brief is available at http://www1.worldbank.org/publicsector/tax/retailtax.htm.

${ }^{18}$ McMorran, R. (1995). “A comparison Between the Sales Tax and a VAT.”In ParthasarathiShome, ed., Tax Policy Handbook. Washington D.C.: Fiscal Affairs Department, IMF.

${ }^{19} \mathrm{~A}$ tax is regarded as buoyant if the tax collection growsat a rate higher than the growth rate of the economy. 
supported by purchase invoices with the mechanism providing strong incentives for firms to keep invoices of their transactions and is an efficient means for tax authorities to check and cross-check for enforcement enhancement. In reality, the tax is not at all self-enforcing because "ghost" invoices and false refund claims are common. ${ }^{20}$ Nonetheless, despite certain inherent problems in administration, VAT is empirically found to be a buoyant tax. ${ }^{21}$ Indeed, most countries started the VAT system with an initial idea of reforming the existing sales tax system on a revenue-neutral basis but then realised that VAT is revenue-enhancing, largely due to the improved compliance. A recent survey by the $\mathrm{IMF}^{22}$ shows that this is true for all regions, except for Central Europe, Russia, and some other countries of the former Soviet Union. By the same token, another advantage of VAT is that being a buoyant tax, it may allow for some relief in income taxes; and if its introduction accompanies a reduction in income taxes, the whole tax system shall tend to be more politically acceptable and hence more stable.

In addition, it is worth highlighting that the consumption-based VAT does not distort the consumptionsavings/investment decision. Since it is realised that being a consumption tax, VAT does not have discriminating effect on savings/investment because savings are essentially excluded from the consumption VAT base.Correspondingly, it should be accentuated that VAT on destination principle may relieve exports from indirect tax burden on inputs if the tax is properly applied. Consequently, under the destination principle, the VAT zero rates exports. In this regard, it is fathomed that if properly applied, the zero rating removes exports from all VAT burden as the exporters shall not collect the VAT when exporting but shall still be eligible to claim for refunds of all the VAT paid on their input purchase. Nevertheless, it is worthwhile noting that this is actually true only in cases where the refunds of the input VAT are made in a timely manner. In practice, it is not uncommon that the VAT refunds are delayed by as long as six months in developing countries; without any interests earned on the portion of the eligible but delayed refunds, thus, enabling export-manufacturing firms to lose in terms of time value for money. Aptly, Desai and Hines argue further that empirically, VAT is associated with less trade (fewer exports and imports). ${ }^{23}$ They explain that in addition to the delayed and incomplete refunds, exporters suffer from exchange rate appreciation, which is likely resulted from the VAT introduction.

\section{Mechanism of the Value Added Tax}

Compendiously, before examining the mechanisms of VAT, it is appropriate to peruse the process of assessing the occurrence of VAT: (i) The manufacturer adds value to the product, with the amount of value added being described as the difference between the cost of the materials used to make the product and the price charged to the customer (often a wholesaler); (ii) The manufacturer pays VAT (a percentage of the value added), which is then included in the purchase price charged to the customer (wholesaler); (iii) The manufacturer gets a rebate from the government for VAT paid on the materials; (iv) The customer (wholesaler) pays VAT on the value they add, which is described as the difference between what they paid to the manufacturer and the price at which they sell it to their customer (retailer), with this VAT amount being included in the price charged to the retailer; (v) The wholesaler gets a rebate for VAT from the government for the VAT paid to the manufacturer; and (vi) The retailer pays value-added tax on the value they add, which is described as the price charged to customers less the wholesale cost and includes the VAT in the final sales price of the product, with the retail store collecting VAT from the person buying the product (retail price thus includes all VATs collected at each stage of this process), thus, gets a rebate for the VAT paid to the wholesaler. ${ }^{24}$

Expediently, therefore, VAT is the tax on the value added at each stage of a production-distribution chain. Apropos, the value added, in turn, is defined in the following two alternative ways. On the one hand, the value added is equivalent to the sum of wages to labour and profits to owners of the factors of production such as land and capital. On the other hand, the value added is simply measured as the difference between the value of output and the cost of inputs. Thus, these two ways of defining the value-added give rise to three major alternatives for computing the

\footnotetext{
${ }^{20}$ For detailed presentation of the most common types of VAT fraud and critical issues in administering refunds, see Brondolo, J. and Carlos, S. (1996). Selected Issues in Administering the VAT: Cross-Checking Invoices and Controlling Refunds to Exporters. Washington, D.C.: IMF. February.

${ }^{21}$ Tait, A. (1988). Value Added Tax: International Practice and Problems. Chapters 2.Washington D.C. IMF.

${ }^{22}$ Ebrill et al., (2001).,op cit.

${ }^{23}$ Desai, M. and Hines, J. Jr. (2002). Value Added Taxes and International Trade: The Evidence. Paper presented at the International Tax Policy Forum/Tax Policy Center Conference on "Tax Systems and International Trade" on 9 December 2002, at the Brookings Institution (Washington D.C.).

${ }^{24}$ Syed Samiul, B. (2016). "New VAT law from July 2017". Dhaka Tribune, 3 June. Retrieved $3{ }^{\text {rd }}$ February 2019.
} 
VAT liability as described below. Firstly, in the 'Addition Method', the tax liability is equal to the tax rate multiplied by the value added defined as the sum of wages and profits. ${ }^{25}$ Therefore, if $t_{1}$ and $t_{2}$ are the rates on wages and profits respectively, then the tax liability will be the sum of $\left(\mathrm{t}_{1} *\right.$ wages) and $\left(\mathrm{t}_{2} *\right.$ profits). The addition method, in practice, would be politically hard to sell to the public, as taxpayers would simply view the VAT as an additional layer of tax burden on top of corporate and personal income taxes. Besides, the structure of the tax implies that the VAT, theoretically, can be used to replace both the personal income tax and the corporate income tax. ${ }^{26}$ Secondly, in the 'Subtraction Method', the tax liability at any stage is equal to the tax rate multiplied by the tax base or value added measured as the difference between the values of outputs and inputs. ${ }^{27}$ Thirdly, in the 'Invoice-based Credit Method' which is considered as the most common method of VAT computation, enables the firm at any stage of the production-distribution chain to charge its customers VAT on its output, submits the tax to the treasury, and then claims for the VAT already paid on its input purchase. ${ }^{28}$ Thus, if $t_{1}$ and $t_{2}$ are the tax rates on output and inputs respectively, then it should be noted that the tax liability is the difference between ( $t_{1} *$ output) and ( $t_{2} *$ inputs).

In a nutshell, it is realised that the invoice-based credit VAT aptly has advantages over both the addition and subtraction methods. This is because while the addition method relies more on accurate information on the wages and profits which are hard to obtain in developing countries, thus, running into the same problems faced in income taxation. By the same token, the subtraction method requires an explicit estimation of the tax base- this would be fine for a VAT with a single rate structure but would result in serious problems for a multiple-rate VAT regime. Therefore, misaligned information, and the resulted monitoring problem inherently make the subtraction method practically hard to apply. While under the invoice-based credit method, the VAT on outputs and inputs is, essentially, assessed and collected separately, and the refunds are credited on the basis of the invoice on input purchases. As the tax base does not need to be directly calculated, the system handles a multiple rate structure more efficiently than does the subtraction method. ${ }^{29}$ Ardently, an extra benefit of the invoice-based credit mechanism is that it requires firms to retain invoices and hence self improves the general record keeping practice. Besides, "selfpolicing”, as a desired character of VAT, is specifically related to the invoice-based credit VAT. ${ }^{30}$

By the same token, it should be noted that VAT is a multi-point tax system without the effect of double taxation, this is because tax is chargeable at the rate prescribed at each point of sale. Thus, in VAT system, the tax is calculated at different points of production and distribution of a commodity and is collected in instalment on the basis of value added at each point of production and distribution. So, since an input is taxed only once, VAT avoids the cascading effect, which is the chief demerit of a generalized system of taxation such as excise and sales tax. Likewise, there are several objectives associated with VAT, foremost being its revenue raising quality, due to the inclusion of items such as wages, interest, profits etc. in its base. As a result, it shall bring in more discipline in the indirect tax regime and also take care of the demerits of the existing system. ${ }^{31}$

\section{The types of the value added tax bases}

The three types of VAT are: 'GNP-typed (Product-typed) VAT', 'Net national product type (Income-typed) VAT', and 'Consumption type VAT', all of which are determined on the basis of treatment of the capital goods of the firm and whether input tax paid for capital goods is allowed or not. While the first type, 'GNP-typed (Product-typed) VAT', taxes all final goods and services except for intermediate goods, investment costs also enter the tax base with no capital expensing or depreciation allowed. Though the advantage of this type of VAT is that the base is relatively large, the big disadvantage is that the investment items will bear the full tax burden. The second type, 'Net national

\footnotetext{
${ }^{25}$ For detailed analysis, see Gendron, P-P. (2008). "VAT Treatment of Financial Services: Assessment and Policy Proposal for Developing Countries." Bulletin for International Taxation 62 (11), 494-507.

${ }^{26}$ This argument forms part of the core of the long-debated topic of tax reform in the United States (see, for example, Slemrod, J., Bakija, J. (2000). Does Growing Inequality Reduce Tax Progressivity? Should It? NBER Working Paper No. 7576, March.

${ }^{27}$ Bakker, C. and Chronican, P. (1985).Financial Services and the GST: A Discussion Paper. Victoria University Press for the Institute for Policy Studies, Victoria University of Wellington, Wellington, NZ.

${ }^{28}$ See Bakker and Chronican (1985)., op cit.

${ }^{29}$ Note, however, the invoice-based credit method cannot escape from the apportionment problem in some complex cases, for example, where a firm produces both exempt and taxed out put.

${ }^{30}$ Minh Le, T. (2003). Value Added Taxation: Mechanism, Design, and Policy Issues, Paper prepared for the World Bank course on Practical Issues of Tax Policy in Developing Countries (Washington D.C., April 28-May 1).

${ }^{31}$ Rehana, I. (2017).,op cit., p. 10.
} 
product type (Income-typed) VAT', does not exclude capital goods purchased from other firms from the tax base in the year of purchase. But, however, excludes depreciation from the tax base in subsequent years, as the tax falls both on consumption and net investment; the tax base is the net national income. Under the third type, 'Consumption type VAT', all capital goods purchased from other firms, in the year of purchase, are excluded from the tax base while depreciation is not deducted from the tax base in subsequent years. The base of tax is consumption since investment is relieved from taxation under this type. Thus, since the consumption type VAT is widely used, the term 'VAT' basically means the consumption-type VAT. ${ }^{32}$

Expediently, it is observed on the one hand that most countries apply the consumption type VAT but introduce various ways of giving credit for capital goods. Rarely do countries allow for immediate and full credit of the tax charged on capital goods. They generally limit the credit in a certain period to the level of the VAT chargeable on output and allow the remaining credit to be carried forward to offset the tax in later periods. ${ }^{33}$ On the other hand, some countries selectively grant immediate exemption of VAT on the purchase of capital goods as part of an overall package of fiscal incentives to priority industries. In this regard, it is important because: Both the product and income-typed VATs entail cascading effect as they more or less charge the tax on investment items. Therefore, they are not production-efficient. Indeed, the income-typed VAT allows for partial and delayed refunds of tax: investment items are not immediately expensed but gradually deducted from the tax base over a specified period in the project's life - the investment items, thus, bear partial tax burden in present value terms. Besides, the GNP or income tax base is relatively larger than the one of the pure consumption-typed VAT and is not commonly applied in practice - China and Brazil are among a few exceptional cases, which apply the GNP-typed VAT $^{34}$. Similarly, it should be noted that the pure consumption base would relieve production from tax burden and hence makes VAT more production-efficient. In addition, as a general consumption tax, the consumption-typed VAT does not distort the investment and saving behaviour.

\section{The value added tax performance measures}

Unequivocally, the concepts of tax buoyancy and elasticity can generally be used to evaluate the performance of VAT or any other type of tax or the whole tax system. ${ }^{35}$ While tax buoyancy is defined as the ratio between the real growth rate of tax revenues and the real growth rate of GDP or GNP, with the data on revenue collection used in estimating tax buoyancy incorporates the impact of any discretionary changes in the tax rate or base or both during the reporting period; and tax elasticity being defined in the same way as tax buoyancy, but for the fact that the data on revenue collection used in estimating elasticity excludes the impact of any discretionary changes during the reporting period. ${ }^{36}$ In this regard, tax buoyancy measures the efficiency of both underlying tax structure and discretionary changes, while tax elasticity measures the efficiency of the fundamental tax structure. Appositely, VAT performance is considered to be satisfactory if the buoyancy or elasticity is greater than or equal to one, thus, signalling that VAT collection is keeping up with the growth of the economy. Other diagnostic tools for VAT performance include the efficiency ratio (E-ratio) and C-efficiency ratio. ${ }^{37}$ With the E-ratio defined as the share of VAT in GDP divided by the standard VAT rate ${ }^{38}$ Aptly, the higher the E-ratio, the better the performance of VAT. Correspondingly, the IMF survey shows that small islands and members of the European Union (EU) have the most effective VAT systems with their estimated E-ratio attained at 48 and 38 percent respectively, while the worldwide average was 34 percent. Nonetheless, it is worth noting that the E-ratio is an imperfect and misleading statistics because: First, there exist problems in measuring GDP, especially in countries with relatively large informal sector. Second, the GNP-typed VAT, where only intermediate inputs are exempted from the base leading to some degree of cascading, tends to improve E-ratio; but however, for economic efficiency, the consumption-typed VAT, which can get rid of the cascading effect if the tax is properly applied, is actually more desirable. ${ }^{39}$ While the C-Efficiency ratio

\footnotetext{
${ }^{32}$ Ibid.; Minh Le, T. (2003)., op cit.

${ }^{33}$ For example, thisis a common practice in Latin America.

${ }^{34}$ For example, China apply the GNP-based VAT at state level.

${ }^{35}$ Shomeprovidesdetailed discussion on taxbuoyancy and elasticity in the context of developing countries.Shome, P. (1988). "On the Elasticity of Developing Country Tax System."In Economic and PoliticalWeekly XXIII (34).

${ }^{36}$ Minh Le, T. (2003)., op cit.

${ }^{37}$ For detailed discussion, seeEbrill et al. (2001).,op cit. pp. 40-42.

38 Thus, an E-ratio of 30 percent, impliesthat if the standard VAT rate isincreased by one percentage point, the shares of VAT revenues in GDP is expected to increase by 0.3 percentage point.

39 Since the consumption-based VAT, by definition, relieves investment costs from the tax base and thereby minimize any potential cascading problem.
} 


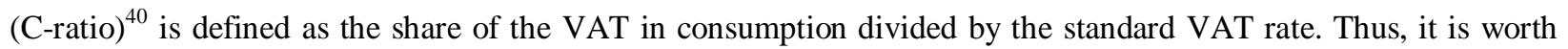
fathoming that this statistic, based on consumption rather than GDP, is a more reliable diagnostic tool than theEratio; with the index being higher or lower than 100 percent. Consequently, the following caution need to be noted: A very high E-ratio, especially, the one far above 100 percent, that may be derived from multiple exemptions in the middle stage or inclusion of investment costs in the base (GNP-typed VAT), does not necessarily mean the VAT is efficient but may instead indicate probable cascading problem. Thus, the further the index deviates from 100 percent, the less efficient the VAT system is. Consistently, with the prediction under the E-ratio, the IMF survey shows that small islands and the EU achieve the best C-ratios of 83 and 64 percent respectively. ${ }^{41}$

\section{Design Issues and Policy Implicationsof the Value Added Tax The origin principle versus the destination principle} Under the destination principle ${ }^{42}$, tax is imposed at the point of consumption, that is, tax on consumption, for a VAT to be effectively imposed on domestic consumption, the tax must be applied on destination principle. Since a destination VAT zero rates exports and taxes imports. Interestingly, the destination principle requires border tax adjustment, with exporters having no incentives to under-declare their export values, and importers no incentives to overvalue their imports as often seen in the VAT on origin principle. Besides, if VAT is properly applied, all inputs are free of tax burden. Indeed, the destination principle promotes production efficiency, that is, a destination VAT puts all firms at different jurisdictions on equal footing: they face the same prices on their input purchase. On the contrary, the origin principle ${ }^{43}$ implies that the taxation takes place in the country of production. That is, the tax is imposed at the point of production: exports are taxed, but imports are not (tax on production). In VAT, exports will be subject to tax, and credit is given in importing country at the rate applied there. The tax burden is the sum of the VAT on the value added generated in the exporting country at its applicable rate, and the VAT on the value added generated in the importing country at its own applicable rate. Origin principle results in global consumption efficiency as consumers in different countries face the same consumer prices ${ }^{44}$, even if the tax rates vary in different

\footnotetext{
${ }^{40}$ Recently, Brondolo (2009) and Sancak, Velloso, and Xing (2010) emphasized the factthat C-efficiency in many countries shows clearco-movementwith output gaps. Sancak et al. notethat C-efficiency has been significantlyaffected by both short-termbehavioral changes, such as in consumption patterns, and the short-term fluctuation of taxpayercompliance, alongwith business cycles. Theyquantifytheseeffects and estimate the elasticity of VAT revenue to movements in the output gap, concludingthat, for advancedeconomies, a 1 percent increase in the output gap in good times isassociatedwith a 1.12 percent increase in VAT revenue collections over one year (aftercontrolling the changes in final consumption) or, equivalently, with a 1.02 percentage point increase in Cefficiency. (SeeBrondolo, J. (2009). "Collecting Taxes during an EconomicCrisis: Challenges and Policy Options," IMF Staff Position Note, SPN/09/17 (Washington: International MonetaryFund); Sancak, Cemile, Ricardo Velloso, and JingXing, 2010, "Tax Revenue Response to the Business Cycle," IMF WorkingPaper 10/71 (Washington: International MonetaryFund)).

${ }^{41}$ Minh Le, T. (2003)., op cit.

${ }^{42}$ The origin and the destination principlescontrastwhicheachother. The application of the destination principleachievedthat the taxation happens in the country to which the goods and services are supplied, so the country of consumption. Thus, the destination principleimpliesthatgoods and services are taxed in the country to whichthey are supplied. Indeed, in a destination principle system, goods and services need to leave the country fromwhichthey are suppliedtax free. The goods and services are thentaxed in the country of acquisition. The rate applicable is the one in effect in the country of acquisition, soitis the same as a local supply. The advantage of the destination principleisthatgoods and services purchasedlocally aretreatedequally to purchasefromabroad (see Ad van Doesum., Herman van Kesteren., Gert-Jan van Norden. (2016). Fundamentals of EU VAT Law, Wolters Kluwer).

${ }^{43}$ According to the originprinciple, if goods or services are supplied to another country, taxation takes place in the country in whichthey are produced and suppliedfrom. Until acquisition of thesegoods and services in that country, not taxation occurs. The main advantage for businesses isthat all their supplies of goods and services are subject to local taxation. However, thereisalso a disadvantage, a local supply and a supplyfromanother country maybetreateddifferently. This canbeproblematic for local businesses when the country fromwhich the goods are suppliedapplies a differenttax rate than the country to which the supplies are made. This canbe an incentive to purchasegoods and services from countries with a lowertax rate.This system alsoimplies an additional administrative burden. Businesses shouldrecover input taxfromforeigntax administrations (see OECD (2017), International VAT/GST Guidelines; Ad van Doesum., et al. (2016).,op cit).

${ }^{44}$ Gross-of-taxprices, adjusted for differences in transportation costs in domestic distribution and foreigntrade.
} 
countries. ${ }^{45}$ Therefore, under the origin principle, there is no need for border tax adjustment as the tax is imposed purely on domestic value added. Thus, proponents of the origin principle claim that this principle virtually eliminates borders and thereby promotes smoother trade, with exports treated just as a normal stage in the whole production-distribution chain stretched, beyond the border of a specific country or state within a federal system. This is the driving rationale for the proposed gradual application of the origin principle to harmonize the VAT system in EU. Also, the proposal calls for the unique VAT treatment in terms of rates and the right to deduct input VAT across the EU member countries.

Conversely, the issue of valuation of imports - in order to correctly remove the imports from the tax base - and of exports - in order to levy the tax - becomes more critical under the original principle than under the destination principle. With importers having incentives to overvalue their imports (in order to claim for more refunds), while exporters have incentives to undervalue their exports (in order to remit lower amount of tax on exports). By the same token, incentive for transfer pricing adds another layer of problem in the origin principle with firms within a multi-national corporation charge artificially high prices on the inputs supplied to firms located in high VAT jurisdiction, which in turn sell their outputs at artificially low prices to firms located in low VAT jurisdiction. In addition, the origin principle tends to induce tax competition among different jurisdictions as importers pay tax at the rate applied in exporting state but receive credit at the rate applied in importing state. Under strict origin principle, on the one hand, if the rate applied in exporting state is higher than the rate in importing state, part of the tax burden on the imports, measured as the difference between the export tax and import refunds, carries on and raises the total tax revenues in the chain. On the other hand, if the VAT rate in exporting state is lower than the one applied in importing country, the total VAT burden gets reduced-part of the burden in the chain is subject to the lower rate applicable in the exporting country. It should be noted that some federal regimes and regional trade associations apply a mix of the origin and destination principles. Specifically, the origin principle is applied to transactions among member states or countries, while the destination principle is applied to those between member and non-member countries. For example, until recently, a number of countries of the Commonwealth of Independent States applied the strict origin principle to their interstate sales and the destination principle to sales to non-member states. They are now switching to a destination VAT uniformly applicable to both inter-state and state-to-non-state member sales. ${ }^{46}$ Brazil applies the origin-like principle to its state-level VAT system which works as follows: Exports are taxed at the interstate sales rate (a standard rate of 12 percent, and a special rate of 7 percent granted to sales to poorer states), and imports are given full refunds. This implies that the effective tax rate is determined by the rate applied at the state of final consumption; the final tax impact is similar to the one under the destination principle although the tax and refund mechanism mimics the origin principle.

\section{The Value Added Tax Exemption}

As discussed above, a non-exemption VAT would avoid the cascading problem and thus would not generate distortion in production. In addition, a broad-based VAT minimizes dead weight loss inherent in any type of indirect tax. $^{47}$ These desirable features of VAT are, however, sacrificed if the tax is riddled with numerous exemptions. Exemption tends to erode the base, reduce the revenue collection on the one hand, break the VAT chain and thereby induce cascading problem on the other. Even worse, exemption is likely to ratchet up: For example, exemption of unprocessed food ultimately exerts pressure on exempting their inputs. Despite all the mischief, exemption is common in practice. In many instances, exemption covers more than just "standard" items such as financial, education, and health services, which are typically exempt for administrative practicability. There are various tempting rationales for exemption. Firstly, there always exists equity rationale for providing tax relief for merit

\footnotetext{
${ }^{45}$ Zeeoffers excellent discussion on the global production efficiencyunder destination principle, and on the global consumptionefficiencyunderoriginprinciple.SeeZee, H. (1995). "Value-AddedTax." In ParthasarathiShome, ed.,Tax Policy Handbook. Washington D.C.: Fiscal AffairsDepartment, IMF.

${ }^{46}$ For example, the VAT legislation in Russiastipulatesthat effective from July 1, 2001, exports (apartfromoil and gasproducts) to CIS countries besubject to zero rate. See PricewaterhouseCoopers. (2002). Corporate Taxes 20022003: WorldwideSummaries. Hoboken, New Jersey: John Wiley\& Sons.

${ }^{47}$ The tax on selectedgoods changes the relative pricesamongdifferent types of goods and services competing for scarce productive resources. A narrow-based sales taxisexpected to cause greaterdistortion in consumptionthan the one induced by a more broad-based sales tax. In essence, anarrow-based indirect taxwouldsignify the substitution effect in consumption, and henceprovidesdistortedsignals to suppliers. Jenkins and Shuklaprovide an analyticalframeworkapplied to a simplifiedtwo-good world.Jenkins, G. and Shukla.G. (1999).Public Finance in Open Economies. Cambridge, Massachusetts: Harvard Institute for International Development, Harvard University.
} 
goods such as education and public health services or goods consumed by the poor such as staple or unprocessed food. In practice, exemption has become a preferable option for reducing regressivity of the VAT. Secondly, exemption is a better option, economically and administratively, than zero rating or reduced rates for the goods and services that require for some tax concession. It should be noted that this is also the main reason for the common practice of exempting merit goods such as basic health service and education. From the economic efficiency perspective, services such as public health and education, generate positive externalities and therefore deserve government subsidies and thus should bear no tax burden. Hence, zero rating, in theory, seems to be the most appropriate $^{48}$. Besides, the problem is that zero rating is extremely complex as it goes hand-in-hand with the requirement for intensified audits and proper refunds. Generally, it is realised that exemption is less costly than zero rating in terms of both tax administration and revenue loss. By the same token, exemption is simpler than the reduced rate alternative, and politically, it is an easier sell to the general public. Thirdly, from the pure administration perspective, it would be more cost-effective to exempt hard-to-tax sectors and groups of taxpayers below certain threshold, as they pose serious challenge to weak administration in developing countries. Some typical examples are agriculture, financial service, public institutions supplying goods or services free of charge or at prices lower than market price, housing, and small traders.

Correspondingly, exemption is always a tempting option for the VAT policy design, but its effectiveness is hard to quantify. For instance, to effectively lower the tax burden on the equity ground through exemption, it is required that exemption should be allowed exactly at the final stage, where the poor consume the good. Otherwise, the tax burden is even higher than that in a non-exempt situation due to the cascading effect. Indeed, the cascading problem may, in turn, induce artificial vertical integration and, in certain cases, nullifies the advantage of the zero-rating granted to exporters ${ }^{49}$. Equally, exemption may also generate another technical problem in compliance and administration, particularly when a firm produces both exempt and taxable items. In this situation, the advantage of the invoice-based credit VAT in dealing with multiple rate structure disappears because the firm is required to apportion its inputs into those used in producing exempt goods and those used in producing taxable goods. In a nutshell, exemption creates numerous efficiency and effectiveness problems as it tends to erode the integrity and sustainability of the VAT system. Thus, it is advisable that the VAT regimes should minimize the number of exemptions to the extent possible.

Succinctly, it should be noted that an exempt stage is completely eliminated from the production-distribution chain, that is, an exempt firm is not required to collect the tax on output sold to its consumers and is not also entitled to claim for the credit of the tax the firm has already paid on its input purchase. Equally, a zero-rated firm that charges no VAT on its consumers (equivalently put, the firm charges the rate of zero percent on its sales) can then claim for refunds of the VAT previously paid on its input purchase. In essence, zero rating does not break the link between the zero-rated stage with others in the whole production-distribution chain, that is, zero rating can be thought of as an extreme case of reduced rate on output of eligible products.

\section{The treatment of hard-to-tax sectors}

Some economic sectors ${ }^{50}$ and groups of taxpayers such as small traders, are practically hard to tax, because they are commonly grouped in the hard-to-tax category. This problem usually arises because of the following: It is administratively hard or financially costly to estimate the value added generated by these sectors, or the compliance costs for the taxpayers are prohibitively high. In the regard, the question therefore is, how can these sectors be treated - or more specifically, should they be included in the tax net and how?

\section{Financial sector:}

It is conceptually and practically hard to tax the financial sector using the invoice-based credit method. One example: a bank gets a deposit at 5 percent and loans out at 15 percent. Under a strict credit VAT, the bank has to divide the total 10 percent value added (i.e., 15\%-5\%) into two parts with one part being the value added generated during the transaction between the lender and the bank while the other being the value added attributed to the

\footnotetext{
${ }^{48}$ As applied in some countries such as Australia.

${ }^{49}$ For example, producers-exporters of agricultural commoditiesmay use VAT-exempt fertilizer; hence, theybear part of the taxburden, embedded in the inputs purchased by the fertilizermanufacturers and carried over to the agricultural exports.

${ }^{50}$ For instance, financial services, agriculture, and housing.
} 
transaction between the bank and its borrower. ${ }^{51}$ The apportionment is next to impossible. Correspondingly, the tax revenue potential in the whole process is expected to be negligible since only the financial services to final consumers/households are taxed, whereas the services catered to firms are treated as intermediate inputs and hence are to be credited. Given the practical problem and insignificant potential revenues, financial services are generally exempted, except for certain types of fee-based services such as brokerage and safe-keeping ${ }^{52}$. In fact, it is realised that despite these seemingly insurmountable problems, Israel attempted to apply a quasi-VAT on financial services using the addition method earlier discussed above, with the tax charged on the profits and wages of financial institutions treated as final tax, with no credit allowed; thus, avoiding the vicious circle derived from the need to estimate the implicit VAT on the amount borrowed by registered firms. ${ }^{53}$

\section{Agriculture:}

It is classified as a hard-to-tax sector for numerous technical, social and political reasons. First, in developing countries, a large part of the sector is informal. Second, from the social perspective, agriculture merits certain special tax relief as most of the poor are active in the sector. Third, the sector hosts most of the political constituents and hence needs to be treated more favourably in taxation. In practice, majority countries have a VAT exempt agriculture. Besides, it is realised that exemption, alone, does not relieve the sector from tax burden because farmers still pay VAT on their input purchase but cannot claim for the credit under a pure exemption scheme. Indeed, the main problem thus entails the need to exempt agriculture and its main inputs, such as farm machinery and tools. In this regard, some countries have opted to exempt farmers and zero-rate agricultural inputs. But, the "stacked" exemption or the combined exemption and zero-rating require effective monitoring - exemption or zero rating must strictly be limited to those inputs used solely by agriculture. Practically, the requirement proves to be too complex to the revenue administration since many items have both farm and non-farm uses, that is, hand tools and general items such as batteries. In addition, multiple exemptions and zero-rating make the VAT exposed to abuse. This calls for the need to bring back agriculture to the tax net. One feasible approach is to introduce high threshold for registration in agriculture. ${ }^{54}$ Expediently, the threshold needs to be the same as the one applied to small traders (more to be discussed below). It is, thus, stressed that for countries that still exempt agriculture, they should critically limit the number of exemptions of inputs to those used for agriculture only, such as fertilizer and seeds. ${ }^{55}$

\section{Small traders and setting threshold:}

In this case, VAT tends to impose high compliance costs on small traders who generally do not have sufficient resources to keep proper records of their transactions and to comply with accounting rules. Besides, the number of small traders is huge, even though including them in the tax net would drain the limited resources of revenue administrations, but the revenue potential is expected to be insignificant because their turnover and value added are generally low. The IMF estimates that on average, the largest 10 percent of businesses account for at least 90 percent of total turnover ${ }^{56}$; this implies that the administration costs incurred in taxing the whole group of small businesses may well outweigh the potential benefits (in terms of extra tax collection). Indeed, this problem is generally resolved by setting a specific threshold, under which businesses are exempted from the tax net even though setting threshold is complex. Some countries, however, recognize that the below-threshold — and hence exempted-businesses bear the burden of the tax on their input purchase and thus allow them to register voluntarily. Expediently, firms in middle stage or selling zero-rated goods/services have strong incentives to register in the VAT net in order to be entitled to claim for their tax credit. Consequently, voluntary registration may extend the base to capture too many small, low-turnover businesses and may conversely nullify the effect of exemption threshold and jeopardize the very purpose of its setting. Practically, there is no standard, "one-size-fit-all" threshold for every country. In this regard, it

\footnotetext{
${ }^{51}$ Minh Le, T. (2003)., op cit.

${ }^{52}$ As appreciated in the EU countries.

${ }^{53}$ Minh Le, T. (2003)., op cit.
}

${ }^{54}$ Somesuggestthatfarmerswith turnover below a specifiedthresholdbeallowed registervoluntarily.Farmerswhosellmost of their output directly to final consumersmay have incentives to remainoutside the VAT regime, whilethoseselling to otherfirmsmayopt to register in. Whileitistruethatvoluntary registration providesadditionaltax relief to farmers, itmayturn out to beadministrativelycostly: the number of registeredfarmersmayincrease to an uncontrollablelevel and become anunbearableburden on the tax administration, but the additional revenue collection isexpected to benegligible.

${ }^{55}$ Minh Le, T. (2003). Value Added Taxation: Mechanism, Design, and Policy Issues, Paperprepared for the World Bank course on Practical Issues of Tax Policy in Developing Countries (Washington D.C., April 28-May 1).

${ }^{56}$ Ibid., p.117. 
is realised that different countries are in different stages of development, different economic structures and have different tax administrations capacities, with the thresholds observed in different countries varying substantially. A recent IMF survey shows that the thresholds range from 0 to $\$ 700,000$ with a mean threshold of $\$ 90,000^{57}$. Even across developed countries, thresholds differ dramatically. For example, Denmark allows for complete exemption to businesses with annual turnover below $\$ 1,500$, whereas the exemption threshold for Japan is over $\$ 200,000 .{ }^{58} \mathrm{In}$ addition, many countries apply different thresholds to different types of activities. For instance, producers may face a lower threshold than the one applied to traders. Many developing countries have weak tax administration but set too low thresholds. The low thresholds generate unintended compliance and administration problems and ultimately threaten the sustainability of the whole VAT system. In practice, many countries start a VAT with a low threshold, but after some "learning by doing" period, they realize the need to adjust the threshold to a new, and significantly higher, level. For example, Ghana set the threshold at $\$ 20,000$ in the first, failed VAT trial in 1995 , but sharply raised it to $\$ 75,000$ in the second, successful introduction of VAT in 1999. Different countries may treat the belowthreshold exempt firms differently. The majority of developing countries do not apply any sales tax to these firms. Some may, however, subject them to turnover or sales tax or some type of presumptive tax. The IMF recommends that for simplicity, efficiency, and transparency of VAT, a high threshold be applied and that the threshold be specified uniformly for all types of activities in terms of turnover. ${ }^{59}$ Countries that just start a VAT may opt to set a relatively high threshold - in order to quench the initial anxiety among small businesses and to make the best use of limited capacity of tax administrations - and then can lower the threshold to a level suitable to the improved administration and to the needs for revenue mobilization.

\section{Housing sector:}

The common practice is that residential buildings and rent are exempted, but office buildings are fully taxed. ${ }^{60}$ Exempting residential building and residential rent is commonly practiced on the basis of both technical and equity grounds. Technically, it is hard to impute rent values for owner occupation because extensive information and subjective valuation are required. But, if residential building is VAT-exempt, residential rent also needs to be exempted to eliminate any discrimination against renting and in favour of owner occupation. The treatment of real estate sales is non-uniform across countries with a VAT, even within the EU. Generally, resale of residential housing is VAT-exempt. Otherwise, there arises the need to tax the purchaser and give credit to the seller; as such, the potential net revenue collection is likely to be minimal, while it is practically complex to apply a VAT credit because the seller may have lived in the building for many years. On the other hand, some may argue that at least, the original purchase of the new housing should be taxed; however, this would increase the market price of housing as owners of old houses would get windfall gain, while it would be unfair to the first-time home buyers. Some countries compensate for VAT exemption of the real estate sales by imposing various transfer taxes, which are, in effect, the tax on turnover. The transfer taxes cascaded through the sale-resale processes but do not generate substantial revenues. From the economic efficiency perspective, these taxes should be removed. Similarly, many countries also exempt construction of residential buildings, with the rationale that if VAT were imposed only on the housing built through contractors, the contractors would be disadvantaged: the market price of housing is increased, but people are expected to switch from hiring contractors to self-building. In this regard, Cnossen offers some broad guidelines for the treatment of the housing sector. ${ }^{61} \mathrm{He}$ argues that the consistent and neutral application of VAT to real estates ${ }^{62}$ would be superior - on both efficiency and equity grounds - to widespread exemption or application of preferential rates.

\section{Public Sector:}

The case in which public institutions provide goods and services on commercial basis, is straightforward. They should be treated in a conventional way, neither exemption nor any other special provision is allowed since they collect VAT on output and claim for credit of their input tax. Indeed, the full taxation treatment would preserve the VAT chain and thereby VAT efficiency while maintaining tax neutrality across public and private sectors. For

\footnotetext{
${ }^{57}$ Ebrill et al. (2001)., op cit. p.115.

58 Tait (1991)., op cit. p.13.

${ }^{59}$ Ebrill et al. (2001)., op cit. p.122.

${ }^{60}$ Taxing business buildings isaclear-cut case.Firmsgetcredit in the VAT system as the rent or building service isregarded as an input.In addition, exempting business buildings wouldbetroublesome: the VAT chainwouldbebroken, and problemssuch as cascadingwouldoccur.

${ }^{61}$ Cnossen, S. (1995). “VAT Treatment of ImmovableProperty.”In Tax Notes International, Vol. 10.

${ }^{62}$ That is, all building activities, forms of leasing, and sales are to betaxedat the standard rates.
} 
instance, New Zealand is the front-runner in extending the VAT base to a large part of the public sector (The VAT is referred to as the Goods and Services Tax-GST). In this regard, Barrand indicates four arguments that support for taxing government departments and local authorities in New Zealand which are "administrative simplicity, accountability and transparency of government operations, comprehensiveness of GST coverage and sound economic management". Basically, there is neither economic nor equity rationale for taxing public organizations more lightly than private firms ${ }^{63}$ Besides, taxing the public institutions that provide goods or services at subsidized prices or free of charge (for instance, state-subsidized public transportation, public museums, and basic food) poses a great challenge. Problems arise in taxing their outputs due to the lack of market prices. The common practice is exemption (for example, in the EU). However, if they are exempt, they become, in effect, final consumers in the VAT chain as they do not have to collect taxes on their outputs but pay tax on their inputs. Hence, they usually request for exemption of their input purchase - the chain of exemptions, if allowed, would effectively be equivalent to zero rating. A long list of subsequent exemptions - or effectively, zero rating — would quickly erode the base. On the other hand, if exemption is not extended to the input purchase by these public institutions, their decision over production will be distorted with their inputs effectively bear burden of the tax. Thus, to overcome these opposing problems, Aujean, Jenkins, and Poddar propose a full taxation model. ${ }^{64}$ In their proposal, they treat public institutions as intermediaries, but not as final consumers (this implies that exemption is ruled out). They equally recognize the complexity in valuing the subsidized outputs and propose that VAT include in its base all explicit fees, subsidies, and grant payments regardless of the funding source. They also suggest that the system be complemented by reduced rates or zero rate for merit goods such as health, and education. ${ }^{65}$

\section{The rate structure of the value added tax}

Explicitly, the multiple rate structure is inherently complex, but yet, many argue for it on both the efficiency and equity grounds. The efficiency argument hinges on Ramsey rule ${ }^{66}$ applied to consumption taxation. The rule specifies that to minimize dead weight loss, tax rate on a good should be set inversely proportional to the good's own demand elasticity. It implies that the rates should be differentiated across different groups of goods and services of various demand elasticities. Besides, supporters of a multiple rate structure on the equity ground argue that tax rate differentiation is needed to mitigate the regressivity of a tax, such that lower rates must be applied to the goods and services consumed primarily by the poor. In practice, however, a multiple rate structure poses a great challenge to tax compliance and administration.

Appositely, a VAT with multiple rate structure requires firms to keep separate records for different purchases. This is in turn costly for auditing (more records to be checked; more incentives and opportunities for firms to misclassify goods) and is cumbersome for application of the self-assessment (complex for taxpayers to comply; and hard for tax administration to detect fraud). In general, a more complex VAT would require tax administration to collect more information to determine the tax liabilities and refunds. While the simplest VAT with a single rate (plus zero rate and a few exemptions) requires at least nine pieces of information from each taxpayer (the value of supplies at the two rates and the value of exempt supplies, the value of purchases at the two rates, two liabilities to VAT on output, and two liabilities to VAT on inputs). At least 17 pieces of information are required if the number of positive rates triples. ${ }^{67}$ Indeed, Cnossen ${ }^{68}$ estimates that for a broadly 'best practiced' VAT in New Zealand (with a single nonzero rate), the administration cost of the VAT is about $\$ 50$ per registrant per annum; but the cost quadruples for the case of the United Kingdom, where VAT is structured with two positive rates and multiple zero rating. ${ }^{69}$

In addition, a reduced rate on items such as basic foods - that account for a large share in total consumption of the poor - is intended to subsidize the poor, but a larger portion of the tax subsidy is, in fact, likely to be reaped by the rich. The rich, by spending more amount on the food, are expected to gain more from the subsidy, whereas the poor is to gain less simply because they spend less amount on the same food items. It is practically hard to measure the

\footnotetext{
${ }^{63}$ Barrand, P. (1991). The Taxation of Non-Profit Bodies and Government Entities Under the New Zealand GST. In International VAT Monitor, (No. 1).January.

${ }^{64}$ Aujean, M., Jenkins, P. and Poddar, S. (1999). "A New Approach to Application of VAT to Public Sector Bodies.”In International VAT Monitor, Vol. 10 (No. 4).

${ }^{65}$ Ibid.

${ }^{66}$ Ramsey. (1927). "A contribution to the theory of taxation". Economic Journal, 37: 47-61.

${ }^{67}$ Tait, A. (1998). Value Added Tax: International Practice and Problems. Chapters 2. Washington D.C.: IMF.

${ }^{68}$ Cnossen, S. (1995)."VAT Treatment of Immovable Property.”In Tax Notes International, Vol. 10.

${ }^{69}$ Cited in Ebrill et al. (2001).,op cit. p.53.
} 
effectiveness if the distribution of this rate reduction-induced subsidy across different income groups; it makes the subsidy less transparent and, thereby, ineffective for targeting equity concerns. However, in many developing countries with a multiple-rate VAT, a large proportion-even more than half of the base, in some cases-is taxed at reduced rates. In contrast, in EU countries, most of the base is subject to the standard rate (for instance, in Spain, 87 percent of the base is subject to the standard VAT rate, while the figure is even higher in Germany with 92 percent). The standard advice by the IMF and the World Bank is that VAT should be structured with a single non-zero rate in addition to zero rate exclusively granted to exports, and few selective exemptions. Currently, more than half of all the countries apply VAT with a single non-zero rate, while majority of the countries (72 percent) that just introduced VAT over the last decade are applying the single-rate structure. ${ }^{70}$

\section{Distributional Impact of the Value Added Tax}

Conventionally, a tax system is considered to be regressive if the share of tax burden in total income is reduced as income rises. Defined this way, regressivity is inherently applied to VAT, a tax on consumption. Expediently, it is noted that many developing countries are tapping into the VAT system with the hope to raise revenues efficientlyat the least collection cost. In this regard, Tait succinctly asserts that VAT is "...intended to be a neutral, efficient, buoyant revenue raising tax". 71 By the same token, tax economists have long suggested that VAT should be designed as a "money machine", but not as a primary instrument to target equity issues. Consequently, as a principle, in designing VAT, it is realised that one needs to refrain from excessive measures to mitigate the regressivity of VAT at the expense of its efficiency. In this perspective, the distributional impact of VAT needs not be analysed in isolation, but in a broader context of the whole fiscal system encompassing both tax and expenditure programs. On the other hand, progressivity is best achieved by complementing VAT with a functioning income tax system, selective excises, and prudent and pro-poor expenditures. With the income taxes and pro-poor expenditures generally regarded as the most direct and cost-effective instruments in dealing with equity concerns. In point of fact, in poor developing countries, the base of the personal income tax is typically narrow with only a small portion of the population falling into the tax net, and tax administrations do not have sufficient capacity to collect the tax properly. Therefore, it is important to maintain a buoyant VAT system to efficiently collect revenues, which are in turn channelled to help the poor through such pro-poor social programs as housing, health care, and education.

Consequently, in this regard, it is worthwhile noting that the conventional definition of regressivity/progressivity has become increasingly questionable, with some critics often citing two major problems: First, it is hard to reliably measure annual income flow. In addition, the welfare impact of any fiscal policy is ultimately determined by the allocation of consumption. As a result, a more proper approach to determine progressivity of a tax system is to consider the share of tax burden in total consumption across income groups. Appositely, if this approach is applied, a broad-based and single-rate structured VAT should, by and large, be proportional but not regressive. Indeed, a growing body of empirical evidence - in the context of developed countries - tends to support the proportionality of a consumption-based VAT. Second, lifetime income, but not annual income, is a relevant concept in welfare analysis. This idea is derived from the observed income fluidity which over time, it is realised that those in the lowest income groups may move up to higher income groups, while the well-to-do may slip to lower income groups. Empirical studies demonstrate that the regressivity of VAT would be substantially reduced when the share of tax burden in total income were analysed on the basis of lifetime, rather than annual, basis.

Conceptually and practically, it should be noted that VAT is no less equitable than any of the alternative consumption taxes. As discussed earlier, when no exemption and/or zero rate is applied, VAT is, in effect, equivalent to a retail sales tax in terms of revenue collection. But in reality, it is worth noting that countries with a VAT system commonly attempt to incorporate in it various progressivity features with multiple exemptions, zero rates, and reduced rates for the goods or services consumed mostly by the poor. In this light, Tait indicates that in UK, zero-rating food and other basic goods consumed by the poor makes VAT even progressive. ${ }^{72}$ Trinidad and $^{2}$ Tobago is another case-in-point. ${ }^{73}$ The country incorporated in its VAT regime numerous zero rates and exemptions

\footnotetext{
${ }^{70}$ Ebrill et al. (2001)., op cit. pp.68-69.

${ }^{71}$ Tait, (1988)., op cit. p.6.

${ }^{72}$ Tait (1991).,op cit. p. 6.

${ }^{73}$ Due, J. and Greaney, F., "The Introduction of a Value-Added Tax in Trinidad and Tobago."In Bird, R. and Casanegra de Jantscher, M. (1992).eds.Improving Tax Administration in Developing Countries. Washington D.C.: IMF.; Ernst \& Young. (1995). VAT \& Sales Taxes Worldwide: A Guide to Practice and Procedures in 61
} 
that were intended to make the system less regressive than the replaced purchase tax. The government allowed for significant VAT relief - including zero rates granted to numerous basic goods in addition to exports, and multiple exemptions covering health-related services, most of education, rental of residential property, bus and postal services - and is committed to funding important transfer programs such as old-age pensions, food subsidies, and public assistance. Indeed, these key developments in the VAT system in Trinidad and Tobago are highly elusive ${ }^{74}$. However, multiple rate structure, excessive exemptions, and numerous zero rating are detrimental to the efficiency of the whole VAT system, add unintended distortions, and impose greater burden on the tax administration. For example, Tait estimates that zero rating food, alone, may reduce the VAT base by up to 40 percent. $^{75}$ Multiple exemptions and zero rates inevitably reduce VAT productivity - this would eventually dry up the funds needed to support the poor, drive governments to make ad-hoc changes in tax policy, and create more uncertainty in the business environment. It is, therefore, crucial not to fall into "equity trap": In many cases, the equity gains are more than outweighed by the efficiency costs.

\section{The value added tax refund system}

As discussed earlier, the consumption-based VAT requires that investment costs and intermediate inputs be effectively excluded from the base. As such, a functioning refund system becomes essential for VAT administration, which is thus a crucial condition for VAT to be an efficient and pure tax on consumption. Therefore, delay in VAT refunds would add a layer of "hidden costs" to registered firms, thereby, discouraging investment. Besides, the

Countries. New York: John Wiley \&Sons.; PricewaterhouseCoopers (2002). Corporate Taxes 2002-2003: Worldwide Summaries. Hoboken, New Jersey: John Wiley \& Sons.

${ }^{74}$ Trinidad and Tobago is an oil-exporting country. The VAT system was introduced in 1989 when income from oil started falling. The advent of the VAT system was accompanied by the elimination of multiple taxes: (1) purchase taxes; (2) excise taxes on edible oils and matches; (3) consolidated special levy; (4) wireless licenses; (5) electricity and telephone taxes; (6) hotel room tax; (7) airline ticket tax; (8) domestic stamp duties (but the stamp duty on imports was retained). It should be emphasized that at the time the VAT was introduced, the purchase tax, the main tax to be replaced, exposed a number of problems. Basically, the purchase tax was levied on goods - on wholesale value basis - while services and most of inputs were exempted. The incomplete exemption of inputs resulted in dual, and yet, seemingly opposite problems: the cascading problem on the one hand, and the narrow base on the other - taxpayers could easily use the loopholes in the purchase tax regime to evade taxes on certain goods (some goods served as both input and consumption). There were multiple rates, and all the rates were high with the maximum reaching 85 percent-the rate structure included 20,40,60, and 85 percent. The complex and unreasonable rate structure, in effect, encouraged avoidance and evasion. The idea of tax reform originated in 1983, and the VAT was considered in 1986. The VAT introduction was part of an integrated comprehensive tax reform covering both direct and indirect taxes. Not until September 1989 was the VAT legislation finally enacted, however. The law went into effect on January 1, 1990. As of 1991, the VAT rate was 15 percent, lower than the lowest rate of the replaced purchase tax. The threshold was set at $\$ 30,000$. Land and buildings were exempted, but the rental of business property and construction services were taxed. The initial VAT was rather complex with multiple zero rates and exemptions to accommodate equity concerns. Zero rating was relatively broad, extended to: (1) unprocessed food and a few basic processed foods; (2) medicines by prescription; (3) live animals, livestock feed, seed, fertilizer, and farm machinery; (4) piped water (5) exports, gas and oil; and (7) veterinary and pest control services. Multiple exemptions covered basic services including public health, education, transportation, real estate brokerage, and financial services. Currently, the standard rate remains at 15 percent. Effective from January 1, 1995, hotel accommodation and yachting services to non-residents are zero-rated. While a number of services including financial services remain VAT-exempt, effective from January 1, 1994, certain financial services are subject to a 15 percent transaction tax. The VAT was administered by the VAT Administration Center of Inland Revenue - but not by Customs and Excise. The VAT was introduced in conjunction with the reduction in income taxes and increase in public funding of pro-poor transfer programs such as old-age pensions, food subsidies, and public assistance. The introduction of VAT was assessed as successful. In the 1991 budget, the tax was expected to yield 25 percent of the total revenue, whereas the replaced purchase tax contributed just less than 9 percent. Some key lessons for the success are as follows. Strong political commitment from the government, careful planning in all stages, from designing to administration. Low introductory rate to pacify the anxiety among the public about the new VAT. (In retrospect, the designers of the VAT even believed that the applied rate of 15 percent was a bit too high and should have been reduced to 10 percent). Close cooperation between businesses and government from the embryonic stage of VAT.

${ }^{75}$ Tait, A. (1988). Value Added Tax: International Practice and Problems. Chapters 2. Washington D.C.: IMF., p.6. 
problem is more serious for export manufacturers who usually have a huge backlog of refunds and also need to compete internationally. For instance, in Vietnam, due to six-month delay in tax refunds, a typical export apparelmanufacturing project would lose 28 cents per each dollar of investment in the present value terms over its lifetime, while the loss to an export leather shoe-manufacturing project would be 5 cents. ${ }^{76}$ By the same token, cross-country experience indicates that delay in tax refunds is common in developing countries. The delay is generally derived from inefficient processing of refund claims and strong incentives for meeting revenue targets on the part of the tax administration, and from the risk of large-scale abuse on the part of taxpayers. In addition, the treasury is under pressure to postpone the refunds during budget-crunching periods. On the other hand, there is legitimate requirement that refund claims be carefully processed, as the refunds normally account for a significant share of the total VAT collection $^{77}$. What is more, the refund issue is tackled differently in different countries. Most cap the amount of refunds of VAT on intermediate inputs and capital items at the level of VAT on output in each tax period and allow for the remaining balance to carry forward over the following period(s). In Ghana, for example, the excess tax credit - or the excess of input tax over output tax — is carried forward for three months, and after that, the refund will finally be made. Another example is Kazakhstan which does not allow for VAT refunds, except for the zero-rated supplies, though all excess input VAT may be carried forward to offset output VAT in future periods. Likewise, some countries may specify a certain time period for VAT on capital goods to be fully credited; this is similar to the specification of fiscal depreciation schedule for corporate income tax purpose, as appreciated with VAT administration in New Zealand. While in some countries, firms are entitled to interest payments on the part of refunds unpaid after a specified period. For instance, tax authorities and treasury bodies are liable for the interest imposed on the eligible non-refunded amount of tax beyond a 14-day term in Russia and 15-day term in New Zealand. $^{78}$ Cogently, VAT refund for exports is a critical issue, since a destination-based VAT zero-rates exports, and thus the sector, is entitled to refunds of input VAT. Conversely, VAT fraud is a common and acute problem, whereby firms may produce false invoices or generate false exports for refunds. As well, some established firms may even engage in the business of selling fraudulent invoices. So, tax administrations are required to prevent such fraud and equally facilitate VAT refunds for genuine exporters. Expediently, efficient programs for processing VAT refunds to exporters deserve special attention.

\section{The Value Added Tax in Small Countries}

Explicitly, a recent IMF survey shows that VAT performs relatively well in small countries and islands (with population of less than 5 million). Consequently, the C-efficiency ratio (C-ratio) reaches 65 percent, on average, in small countries and is especially high in small islands ( 83 percent), whereas the world average is 58 percent. ${ }^{79}$ Conversely, it is worth noting that a relatively high C-ratio does not necessarily guarantee that being small is advantageous for adoption of VAT. This is because indirect taxes including VAT are likely to perform better in countries which rely more on foreign trade. Prest further argues that the overall tax capacity of a country is positively correlated with the size of trade. ${ }^{80}$ Besides, Alesina and Wacziarg empirically demonstrate that trade and country size are negatively correlated, that is, a smaller country is more likely to have more trade. ${ }^{81}$ As a result, the high C-ratio observed in small countries and islands, may simply indicate the following sequence of correlation; as being small tends to raise the importance of trade, which in turn favourably improves the VAT productivity. Therefore, it should be noted that when a country relies more on foreign trade, the tax administration may shift its focus to a few check points at the border, thereby reducing collection cost, and raising more tax revenues.

By the same token, for smaller countries with more trade, any type of indirect taxes - be it trade tax, or excise, or VAT - tends to be more efficient. Besides, it is worthwhile noting that in small countries, the consumption-toimport ratio is typically low, and a broad-based tariff system may well capture most of the consumption base. From the collection efficiency perspective, trade taxes may even be superior to other types of consumption taxes including

\footnotetext{
${ }^{76}$ Minh Le, T. (2003).Analysis of Tax and Trade Incentives for Foreign Direct Investment: The Case of Vietnam. Ph.D. thesis. Cambridge, Massachusetts: Kennedy School of Government, Harvard University. January.

${ }^{77}$ It isestimatedthat in EU countries, the amount of the VAT refundaccount for 25-35 percent of the total VAT collection, while the figures stand at 30-40 percent in mostdeveloping countries.

${ }^{78}$ Minh Le, T. (2003)., op cit.

${ }^{79}$ Ebrill et al., (2001)., op cit. pp. 41, 167-68.

${ }^{80}$ Prest, A. (1979). "The Taxable Capacity of a Country."In J.F. Toye, ed., Taxation and Economic Development, chapter 1. London: Frank Cass.

${ }^{81}$ Cited in Ebrill et al., (2001).,op cit. p.169.
} 
VAT ${ }^{82}$ Correspondingly, VAT being a general tax (imposed on both imports and domestically produced goods), possess some important advantages, that is, VAT is less distortionary and has more revenue potential than tariff alone. ${ }^{83}$ In addition, VAT may help jumpstart the construction of an efficient tax administration. In certain extreme cases, the consumption-to-imports ratio converges to one: this is the case for small islands that virtually have no domestic manufacturing base. Then, the revenue and efficiency implications of tariff, VAT, and any other type of consumption tax (retail sales tax or excise) are, in theory, expected to be the same. A legitimate question for the practicality of the tax policy design is, whether VAT is necessarily a better choice for taxing consumption? Typically, VAT is an option when (i) a country has domestic manufacturing base with multiple production stages or has distribution stage generating significant value added; (ii) if the first condition is currently missed, the country has sufficient growth potential for domestic manufacturing. Thus, for small islands without either of these two conditions, VAT may not be a sensible choice, whereas a single-stage sales tax on border entry or at factory gate supplemented by an excise on selected services may be more suitable, administratively and economically. In this regard, it is appropriate to proceed by assessing the drifts and challenges of VAT in Cameroon.

\section{Nature and Drifts of the Valued Added Tax in Cameroon}

As aforementioned, the introduction of VAT can expediently and substantially facilitate in the improvement of the overall tax administration of a country; with its adoption often seen as an opportunity for the overall modernization of the tax administration. Consequently, the main pertinent decision is where to place the VAT administration within the overall tax administration. In this regard, Kommer and Waris argue that for tax reforms to be successful there is a necessary precondition that the National Treasury, responsible for tax law and policy formulation, must have a strong link, understanding, and coordination with the tax administration from day one of the tax reform measures, ${ }^{84}$ such as the introduction of VAT. Thus, following the introduction of VAT in some countries, it appears that no clear link was made between the formulation of the policy, clear assessment of feasibility and the means and resources through which the tax authorities were to implement it. Expediently, it is observed that most countries have made the collection of all taxes on imports, including VAT, the responsibility of the customs department. Likewise, it is realised that irrespective of the type of organization recommended, there needs to be close coordination of VAT preparations between the income tax administration and the customs department, though this coordination has been very poor in some countries. In addition, an important and less settled issue in a few countries, is the question of who should administer the domestic VAT and account for the tax collections on imports reported by customs. In this connection, there are three possibilities: (i) administration of VAT by the department responsible for domestic tax operations (including personal and corporate income taxes, and, in several countries, social contributions); (ii) administration by a separate VAT department; and (iii) administration by the customs department. Contrariwise, it should be noted that the introduction of VAT in some countries occasionally disrupted the functioning of the existing tax administration because of inadequate preparations and/or ill-advised implementation decisions. Nonetheless, in Cameroon, as perused below, the introduction and application of VAT, is considered as the most significant tax reform ${ }^{85}$ that ever occurred during the 1990s.

\footnotetext{
${ }^{82}$ Ebrill et al., (2001)., op cit.

${ }^{83}$ From the pure economicefficiency perspective, the VAT generatesonlydistortion on the consumptionside, whereastariffinducesdistortion on both production and consumptionsides. The VAT isalso more advantageousthantariff in terms of revenue potential: the VAT iseffectivelyequivalent to the taxregime, wheretariffiscombinedwithtariff-equivalent excise tax on domestic production.

${ }^{84}$ VonKommer, V. (IBFD) and Waris, A. (University of N. (n.d.). Bulletin for International Taxation 2011, No.11, pp. 620-636. pdf.

${ }^{85}$ Tax reform is the main component of macroeconomic policy and is considered as the most important part of fiscal policy and also in agreement with monetary policy (See Holban, O. (2007). The taxation of small and medium-sized enterprises-a hindering factor influencing the european economic growth. Doctoral dissertation, AlexandruIoanCuza University of Iasi and Academy of Economies Studies from Bucharest Romania). By the same token, tax policy depends on its use as special tax preferences and/or as an incentive to support start-up and business growth. Indeed, the aim of tax reform is to raise revenue effectively in consistence with each country's uniqueness and administrative capacity. Analysing a country's situation before employing any tax reform results to a proper functioning tax system. With the objective of tax reforms being to save collection cost while reducing the revenue loss as well as minimal economic disruption, less inequity and reduction in tax burden. Mostly, tax reform seeks to improve the efficiency and productivity of taxation (see Wagacha, M. (2009). Fiscal policies and their macroeconomic implications for Kenya. In Kimuyu, et al., eds., Kenya's Strategic Policies for the $21 \mathrm{st}$
} 
Essentially, as discussed above, VAT is an indirect tax on expenditure charged on most goods and services to be borne by the final consumer in the distribution and consumption cycle. Correspondingly, it is worthwhile highlighting that VAT was introduced in Cameroon by the Finance Law No 98/009 of $1^{\text {st }}$ July 1998, in effect since $1^{\text {st }}$ January 1999, replacing the turnover tax. As a consequence, the Finance Law No 98/009 introducing VAT and Part II of the General Tax code (GTC) as edited annually, are the two major laws regulating VAT in Cameroon under the auspices of the Tax Authority ${ }^{86}$. In this connection, Section 142 of the GTC provides the two rates of VAT applicable in Cameroon, as enshrined in the finance law as follows: (i) The standard rate at $19.25 \%$ (17.5\% as principal rate plus $10 \%$ of the principal rate $-10 \%$ of the $17.5 \%$ as additional council tax rate); and (ii) the zero rate of $0 \%$ for zero-rated transactions, which applied on taxable exportation transactions and transactions carried out in the free trade zone.

By the same token, there are three essential conditions used in defining the domain of application or scope of VAT in Cameroon, such as the persons concerned, the transactions in question, and the territory concerned, as expediently analysed in seriatim as follows:

1. Taxable personsare those who are or should be registered for VAT, because they carry out taxable transactions. Thus, according to Section 125 of the GTC, all natural (individual or physical) and artificial (legal or moral) persons whatever their legal status - who independently, usually or occasionally carry out taxable transactions that fall under the domain of VAT in Cameroon are liable to the application of VAT. Conversely, it is worth noting that with respect to natural persons, it provides that only those who realize a minimum annual turnover of 15,000,000 CFA Francs should be registered for VAT.

2. Taxable transaction by their nature,indeed,by virtue of Section 126 of the GTC, only transactions carried out within the context of an economic activity against payment shall be liable to VAT. Apropos, taxable transactions have to fulfil the following conditions: be profitable and valuable delivery of goods or provision of services, carrying a financial compensation from the beneficiary; be undertaken by taxable person; be part of an economic activity; and not appear on the list of transactions exempted from VAT as enshrined in the finance law.

3. Taxable transactions due to the special provision of the law, involve those transactions that would normally not have fallen within the domain of VAT, but the law in Section 127 of the GTC makes them taxable. These include: supplies for own use (production for own use); the renting of undeveloped lands by professionals (real estate agents); the sales of second handed items by professionals in this domain; the importation of goods; all transactions on landed properties carried out by real estate agents; the disposal of tangible fixed assets not found on the list of items exempt from VAT; the sale of petroleum products, whether imported or produced in Cameroon; and the games of chance and entertainment. Cogently, from the overview, it is worthwhile and expedient to assess the drift and viability of VAT in Cameroon.

\section{The drifts and viability of VAT in Cameroon}

As aforementioned, the coming to effect on the $1^{\text {st }}$ January 1999 of the Cameroonian VAT system ${ }^{87}$, is a significant and overwhelming achievement to alleviate the financial sector. In fact, according to the positive theory of taxation as earlier discussed, VAT is an indirect tax that can substantially minimize excess tax burdens. Besides, it is realised that VAT is preferred to other taxes because of its greater allocative efficiency and higher yield. In this connection as per the provisions of VAT in the GTC, it is worth appreciating that the VAT system of Cameroon conforms to a greater extent with the tax rules that had been accepted and reinforced since 1980 at the international level with the Structural Adjustment Programme (SAP) and trade liberalization. Correspondingly, in Cameroon, the major activities subject to VAT are production, provision of services, distribution, construction work, and real estate

Century:Macroeconomic and Sectoral Choices. Nairobi: Institute of Policy Analysis and Research (IPAR)). Wagacha, thus, asserts that tax reforms can be split into three as follows: custom reforms, VAT and excise duty reforms, and income tax reforms. Equally, Cobham stipulates that in order to achieve the tax reforms, it is of great importance to first strengthen the administrative capacity of the tax institution. The strengthening measures that need to be taken include taxpayers' e-registration, e-tax filing, and introduction of stifle tax penalties, taxpayer education and taxpayer services (see Cobham, A. (2005). Tax evasion, tax avoidance and development finance. The Oxford Council on Good Governance, 6(4), 8.)

${ }^{86}$ 'Direction Générale des Impôts de MINFI'

${ }^{87}$ See Finance Law No 98/009 of $1^{\text {st }}$ July 1998 as implemented on the $1^{\text {st } J a n u a r y ~} 1999$ to replace the former turnover tax - as readwith the General Tax code (GTC) of Cameroon. 
agencies. Cogently, to revamp the buoyancy and effectiveness of VAT in Cameroon, the following policy drifts are assessed:

1. Exemption measures under VAT:Thus, owing to the characteristics of most farms (small family farms), and in order to maintain the competitiveness of their exports, it is not possible to subject these to VAT. Besides, it is observed that the solution granted by the 1999 Finance Law on VAT inCameroon, instead granted exemption to agricultural inputs such as insecticides, fertilizers and their packaging from VAT, which were equally complemented by tariff exemptions. likewise, VAT exemptions have also been used to lower the cost of certain sensitive products, notably in the area of health, such as the single use syringes and packaging of medications, etc. What is more, basic necessities, medical drugs, health, etc. have also been exempted. As aforementioned, Cameroon applies a single rate of 19.25 per cent (including communal special surtaxes), and a zero rate. ${ }^{88}$ Correspondingly, it is noted that the application of the single rate is justified in technical terms as necessary for the successful introduction of VAT in countries with weak administrative capability. By the same token, the goal of a single tax rate is to improve the tax yield by facilitating its administrative management, and curtailing opportunities for tax evasion. ${ }^{89}$ Besides, the multiple tax rates generally imply significant management and supervision costs. In a nutshell, VAT exemption has been extended to interest paid on loans of less than 2,000,000 CFA Francs, granted by second category microfinance institutions to their members. ${ }^{90}$

2. VAT in Cameroon is combined with the excise tax: Excise duties are levied on particular goods and services and are extended to the profits of financial monopolies. Moreover, the IMF defines these as 'taxes levied on particular products or a limited series of products; which may be imposed through each step of the production or distribution process, and may be determined on the basis of weight, content, quantity of a product, or on the basis of value'. ${ }^{11}$ Indeed, the most important excise duties are taxes traditionally levied on tobacco, alcoholic beverages, cosmetics and oil products. Thus, in Cameroon, it is realised that the products subject to excise taxes (at a rate of 25 per cent) are tobacco products, alcoholic beverages, perfumes and colognes, cosmetic and makeup products, hair lotions, precious stones and metals, jewellery, etc.

3. Tax relief and simplification of the income tax system: Interestingly, the simplification of the income tax system also constituted a significant aspect of the tax drifts in Cameroon during the 1990s. Thus, in order to reduce the tax burden and improve the efficiency of tax administration, the reforms gave priority to the simplification of the existing 'cedulaires' taxes, and to the development of a system of tax deduction at source, notably with regard to wages and salaries, or income resulting from professional activities, which is particularly difficult to assess in the context of a system where tax returns are not filled out. At this juncture, it is appropriate to consider the major reforms in tax administration and the effect of VAT in Cameroon.

\section{The effects of VAT reforms in Cameroon}

Essentially, the increase in domestic revenue is well recognized and significant since the beginning of socioeconomic and infrastructural development in Cameroon. Aptly, since more than 80 percent of total revenue comes from taxes, the restructuring of the tax system by introducing VAT in Cameroon was very crucial, as it relies heavily on trade taxes. Besides, studies of the tax structure of certain developing countries suggest that the economic cost of trade taxes is much higher than domestic consumption taxes, with the trade taxes hampering the efficient creation of domestic industries by penalizing exports. ${ }^{92}$ Thus, it is observed that the tax structure before introducing VAT was inelastic, unresponsive to the growth in overall economic activity, with taxes on agricultural income and property incomes being negligibly and poorly administered. Therefore, in order to ensure self-reliant growth and reduce external dependence, the domestic resource mobilization efforts in Cameroon have to be graded up. Appositely, to keep pace with the ever-growing public expenditure, which is required to meet public needs and make the resources available for development efforts, there is no substitute for a comprehensive tax reform which is aimed at raising

\footnotetext{
${ }^{88}$ See Finance Law No 98/009 of 1st July 1998 as implementedfrom 1st January 1999 and the General Tax code.

${ }^{89}$ Cornély, J-P. (1995). 'Conditions pour la réussite d'une TVA en Afrique'. Les Journées d'étude Coopération Française, Banque Mondiale, FMI, mai 1995 ;Shome, P. (ed.). Tax Policy Handbook. Washington, DC: IMF.;Tanzi, V., and Zee, H. (2000). 'Tax Policy for Emerging Market: Developing Countries'. IMF Working Paper WP/00/35. Washington, DC: IMF.

${ }^{90}$ See Article 128 (25) of the Finance law of 2018 and the General Tax code (GTC). Also, several types of interestpaid on externalloans, deposits are alreadybenefitingfromthis exemption.

${ }^{91}$ International Monetary Fund (IMF) (1974). 'A Manual on Government Finance Statistics'.Draft. Washington, DC: IMF. 1974. p. 166.

${ }^{92}$ Rehana, I. (2017)., op cit., p. 14.
} 
revenue as well as eliminating the tax-induced distortions in the structure of the economy. Apropos, the introduction of VAT is the centrepiece of this reform effort. ${ }^{93}$

Pertinently, in this connection, significant progress was made during the 1990s to improve the organization and functioning of Cameroon's tax administration, thus, increasing its capability to manage the tax system. Among the key measures implemented during the period, is in particular the creation of a service responsible for managing the taxation matters of major taxpayers and large enterprises. Cogently, until the 1990s, large enterprises, from which the bulk of taxes are collected, were not closely monitored by tax authorities. As a result of the economic crisis that hit the country in the late 1980s, thus, the need to increase tax revenue and improve supervision, induced the government to establish a specialized service to manage these big taxpayers within the context of donor-supported reforms. In this connection, the following measures were decisive in improving tax collection and initiating the reform of tax administration: The organization of external and central services within the government; the establishment of a taxpayer registration system; the improvement in taxpayer education and information, and the development of data processing capabilities to facilitate tax management. ${ }^{94}$

By the same token, it is interesting to note that non-oil tax revenue, although showing a declining trend up to 1993/4, witnessed a net recovery starting from 1994/5 as a consequence of the implementation of the reforms. ${ }^{95}$ With the most significant rise occurring in such domestic revenue as corporate income taxes, taxes on goods and services including VAT, income taxes, etc. Indeed, this rise was mainly driven by taxes on goods and services, the level of which increased on average by almost 33 per cent per annum, thanks to the economic recovery. Besides, foreign trade taxes were also rising during this period as a result of an increase in VAT on imports of goods and services. Thus, as aforementioned, non-oil tax revenue was dominated by foreign trade taxes before and during the 1990s, followed by taxes on goods and services. As a result, from 1994/5 until 2001 when both the turnover tax and VAT were applied, the share of turnover taxes in non-oil tax revenue continuously increased, contributing to the rise in revenue on goods and services. ${ }^{96}$

Compendiously, as concerns the effect of VAT in Cameroon, it is interesting to note that studies on the effects of taxation in Cameroon are rather rare. Thus, in this regard, the only empirical study on this topic is that of Emini ${ }^{97}$, who using a computable general equilibrium mode, evaluates the impact of an imperfect VAT with reference to that applied in Cameroon. This evaluation is based and made on the allocation of labour between sectors of activity, on public finance, and household welfare. The simulation results show how an imperfect VAT can generate effects opposite to those of a perfect one, especially with regard to resource allocation. Besides, the model also helps to verify certain theoretical assumptions such as the fact that substituting a perfect VAT for cascading taxes, for example, induces a relatively greater demand for productive factors in activities whose tax burden was heavier in the cascading system. ${ }^{98}$ By the same token, the simulations also show that despite its imperfect nature, the VAT implemented in Cameroon is economically more desirable than the ex-ante tax status quo because it generates a substantial increase in tax revenue, improves the budget deficit, and stimulates investment. But conversely, these positive effects are diminished by the subsequent deterioration of household welfare. Nonetheless, this deterioration may only be transitory to the extent that the increase in investment may give rise with a time lag to an improvement in household welfare. In sum, it is observed that the tax system will be more buoyant and favourable to the economy as a whole as long as VAT becomes more neutral.

\section{Challenges of the Value Added Tax in Cameroon}

Generally speaking, it is worthwhile noting that while the net benefits of VAT depend to some degree on the circumstances of the individual country, however, experience indicates that VAT has proved to be very appropriate for developing countries like Cameroon. Besides, it has been a core component in the broad trend toward tax reform as evident in many developing and transition countries. Correspondingly, it is realised that while much still remains

\footnotetext{
${ }^{93}$ Harmachi, A. (2016). "Bangladesh lifts VAT on computers, spares". $2^{\text {nd }}$ February. Bdnews24.com.

${ }^{94}$ Fambon, S. (2006). Taxation in Developing Countries: Case Study of Cameroon, United Nations University (UNU-WIDER), ResearchPaper No. 2006/02.

${ }^{95}$ Ibid.

${ }^{96}$ Ibid.

${ }^{97}$ Emini, A. (2000). 'Analyse de l'incidence d'une TVA imparfaite à l'aide d'un modèle calculable d'équilibre général, Application au cas Camerounais'. Cahier de recherché $n^{\circ}$ 00-06. CREFA, Université Laval.

${ }^{98}$ Ibid.
} 
to be done, VAT has served to stabilize and bolster revenue mobilization in Cameroon as in many other countries while contributing in revamping economic efficiency. Likewise, the complexity of the indirect taxes that VAT has typically replaced belies the concern that VAT is inherently "too complex" for developing countries. By the same token, empirical analysis indicates that the importance of international trade, high literacy, and the length of time VAT has been in place has readily enhanced VAT revenues. So, it is observed that while the latter two factors imply that the tax is "more successful" in the developed countries, there is empirical evidence that it has also been "successful" in many developing countries. Ardently, despite the merits, it is worth noting that there are some specific challenges of VAT in Cameroon as indicated below:

1. The choice between a single-rate and a multiple-rate VAT which depends mainly on balancing the tax administration considerations favouring the single rate, against the availability of other instruments, better targeted to achieve the distributional objectives, the relative absence of which tends to favour further rate differentiation. But, in any event, the extent of redistribution that can be achieved by VAT rate differentiation is typically very limited. For these reasons, most experts favour a single rate. Besides, the role of VAT within broader strategies for alleviating poverty and achieving fairness is readily attracting continuous attention in this current era.

2. The zero rate should generally apply only to exports, that is, using exemptions instead where it is deemed essential to reduce the tax burden on a given good or service. Likewise, it is realised that this is not the best approach from the policy standpoint; because exemptions seriously compromise the logic of VAT. However, in light of the major problems with refund control in developing and transition countries, exemptions may reflect a logical second-best solution.

3. The efforts to eliminate exemptions are likely to figure prominently in coming years. In fact, exemptions are fundamentally inconsistent with the economic logic of VAT, creating their own distortions and difficulties of administration and compliance. The appreciation of these weaknesses, and the limited benefits they offer, seems likely to increase, thus, needing pre-emptive measures and actions to alleviate and buttress the situation for better performance.

4. The case for a relatively high threshold is strong. In contrast to the single-stage taxes, such as a retail sales tax, a threshold can be introduced without a significant revenue loss, thereby facilitating the implementation of VAT. Besides, even great support for simple presumptive taxes below the threshold would help to assuage the concerns over the equity and allocation implications of exempting those below the threshold from having to collect and report the tax. There is also support for differentiated thresholds (in order to accommodate systematic variations in value added across sectors), though this requires further analysis in light of the administrative implications.

5. The inter-jurisdictional aspects of VAT — both internationally, within trading blocs, and inside the country will require increasing attention in coming years. Issues here include the proper role of the VAT within the country and determining the proper form and extent of coordination in design and implementation of a buoyant and effective VAT system.

6. The increasing importance of trade in services and electronic commerce poses new challenges for international and intra-state tax design. Clearly, these are areas that warrant further analysis and discussion, as with the OECD's current work on services and intangibles. In this regard, the organization of an overall structure of tax administration is likely to require even more attention, both in conjunction with the introduction of VAT and beyond to ensure sustainability.

7. The lack of success in implementing appropriate self-assessment proceduresmeans that, in these cases, the effective implementation of VAT will take longer than had been envisaged. It remains the case that it is not possible to have an effective VAT without self-assessment. In this connection, the development of effective audit procedures is clearly an area in which many countries especially Cameroon require significant improvement.

8. There are serious problems, almost everywhere, with refunding of excess credits. Expediently, it is observed that the theoretical need to issue refunds is one of the most important factors that differentiates VAT from the taxes which it replaced in Cameroon. In addition to the reluctance of financially weak governments to pay refunds, it has become increasingly apparent that many tax administrations are incapable of policing the issuance of cash refunds to taxpayers without inviting abuse. Aptly, it is fathomed that this can be addressed through a combination of compromise measures to improve the operation of refunds (for instance, focusing on relief for exporters), and, on a transitional basis only, the adoption of measures designed to work around the need for refunds (in the case of investment, in particular).

9. In a nutshell, there is an inappropriate strategic approach to VAT losses based on sound management in Cameroon.In essence, this overarching strategic approach need to be revamped, to aid the government establish 
effective and targeted counter-measures and the ability to monitor tax administration performance in the various domains. Besides, the range of challenges ahead-improving the structure and implementation of the tax, dealing with the new challenges posed by international services, electronic commerce, regional integration and trade liberalization - mean that VAT will still remain on the reform agenda for many years to come in order to follow with the trends of globalization.

\section{The Benefits and Drawbacks of the Valued Added Tax in Cameroon Benefits of VAT}

Unequivocally, the introduction of VAT concept was a spectacular fiscal phenomenon and panacea. It is interesting to accentuate that within a short period of time; the tax has exploded from its rudimentary form to become the stateof-the-art tax on goods and services all around the world. In this contemporary era, VAT has a significant impact as the most efficient, broad-based and revenue-productive system of indirect taxation. Likewise, it has been increasingly adopted by many developing countries around the world like Cameroon, that share the same policy objectives of development and socio-economic stability and are subject to the same constraints that may affect the buoyancy and efficiency of the tax administration. Apropos, despite the challenges of the VAT system in Cameroon as fathomed above, with the aid of the perusal of the subject under consideration, the followings are some of the benefits of VAT that are envisaged for Cameroon:

1. Neutrality, certainty and transparency: The greatest merit of the system is that it does not interfere in the choice of decision for purchases. This is because the system has anti-cascading effect and is neutral with regard to the choice of the production techniques, as well as business organization. Besides, the issue of tax liability does not readily vary the decision about the source of purchase. Similarly, VAT is a system based simply on transactions. Hence, there is no need to go through complicated definitions like sales, sales price, turnover of purchases and turnover of sales. As well, the tax is broad-based and applicable to all sales in business, thus, there is little room for different interpretations. Likewise, due to the basic feature that it gives credit of tax paid on earlier stage, the buyer will always ask for invoice. As a result, the scope of tax avoidance or evasion will be much less and disputes fewer. The system brings certainty to a great extent as the buyer knows the tax component, thereby, ensuring transparency.

2. Widespread usage and a harmonized system of taxation: Expediently, VAT is in use in well over sixty countries throughout the world. In its usual form, it is a transaction-based consumer tax applicable to both goods and services, with the invoice acting as the basic evidential document. As earlier reiterated, it is neutral in effect, with the tax liability on sales (outputs) being offset by the tax paid on purchases (inputs). In this regard, it avoids cascading. Cogently, VAT has become popular because of its built-in advantage of harmonizing the tax structure and leaves very small room for interpretation. Ideally under VAT, there need to be only one basic rate. But typically, VAT involves lowering the number of tax slabs/rates resulting in the reduction of litigation.

3. Exports and better revenue collection and stability: Congruently, VAT frees exports from the burden of tax in that the tax paid on inputs can be identified and recovered by the exporter. Consequently, goods enter into international trade on an equal footing in this respect with those from other countries. By the same token, with the VAT system, the Government usually receive its due tax on the final consumer/retail sale price. There is a minimum possibility of revenue leakage, since the tax credit will be given only if the proof of tax paid at an earlier stage is produced. Another attribute of VAT is that it is an exceptionally stable and flexible source of government revenue. The stability of VAT as a revenue source stems from the fact that if consumption is less volatile, the income system provides a flexible instrument of taxation, since it is collected on a current basis. Equally, the decision about revenue can also be taken correctly as variance in rate of tax has directed relation with revenue collection.

4. VAT as an aid to tax reform and planning skills: A full VAT paid on imports and extending throughout manufacturing, wholesale/distribution and retail businesses - and including services - provides a wide tax base and, depending on the state of the economy, a buoyant source of revenue. Likewise, in order to produce good results, the introduction of VAT, whether a full or partial system, needs to be carefully planned. This requires the setting up of a team dedicated to the work and allows new skills to be developed, possibly with the assistance of consultants who have been involved in such projects in other countries.

5. Increased administrative capabilities and enhanced relationship with taxpayers: The introduction of VAT requires the drafting of new law and regulations. For the administration, this will involve the setting up of new organizational structures, the designing of new procedures and forms, writing of new instructions, arranging for the provision of better management information and statistics, etc. This gives the administration the opportunity to develop new skills and abilities which can subsequently be deployed right across the tax systems. As well, a necessary feature of VAT is the introduction of computer systems or the enhancement of those currently in 
operation. Plainly, in some developing countries like Cameroon, contacts between the administration and the taxpayers are limited to routine control duties, enforcement and audit activities. As a result, the introduction of a new tax allows a fresh approach to be made, with publicity campaigns being designed with a view to improve the taxpayer's view of officialdom.

6. Better record keeping by the business community and use of unique numeric identifiers: Appositely, the control of VAT rests on the use of invoices and the keeping of records by the taxpayers. In this connection, much will depend on the level of turnover at which businesses are required to register for tax. If the level is set too low, the cost of adequate control may become excessive. In a nutshell, good publicity aimed at educating the taxpayers on the requirements of the tax, thus, facilitating its administration and can generally lead to the improvement of business procedures. Similarly, for VAT, it is essential that each business registered for the tax is identified by means of an identification unique number to that business. Where a suitable system of numbering already exists, it should be used for the VAT. Where it does not, a system of unique numbers (incorporating check digits) need to be developed.

7. Training: An essential element of progress in neglected areas in many administrations is training. Good training is expensive to design and carry into effect, but the rewards are great. Work is done better and complaints are fewer; there is greater flexibility in the use of staff whose morale and motivation are improved. As a result, costs are reduced. To introduce a new tax with any degree of success, staff at all levels must be well trained from junior clerks to top management. This provides a further opportunity to improve on past performance. In the case of VAT, the experience is gained in such matters as reviewing and redesigning training organizations, obtaining accommodation where this is currently inadequate, obtaining modern training equipment, preparing new course material, examining and improving training methods. VAT simplifies tax administration and increases efficiency in resource allocation.

\section{Drawback of VAT}

Despite the aforementioned benefits, it is interesting to note that the VAT system is not free from its limitations. Since no matter how well efficient and effective a system is developed, it still has to face some drawbacks, as provided below:

1. The price effect of VAT on retail price: A persistent criticism of the VAT form has been that since the tax is payable on the final sale price, VAT usually increases the price of the goods. However, there appears to be an intrinsic reason as to why there should have any inflationary impact, if it merely replaces the existing equal yield tax. It is possible that the final price under the VAT system may not be more than the price under the sales tax system. A survey of the price effect of introducing in more than 130 countries resulted in a conclusion that in more than $80 \%$ countries it did not alter the rate of inflation. ${ }^{99}$ Besides, it may also be pointed out that with the introduction of VAT, the tax impact of raw material is to be totally eliminated.

2. The cost of administration to the country: Another point which needs consideration is the question of the cost of VAT administration to the Country. This is because the introduction of VAT, entails the administration cost to the country can increase significantly as the number of dealers to be administered will increase significantly. Nonetheless, this increase need to be evaluated against the likely gains under the VAT, in order to have a clearer picture.

3. Compliance cost to the dealers and increase in working capital requirement: It is argued that compliance with the VAT provision, increases accounting cost. However, the burden of this increase may not be commensurate with the benefit to traders and small firms. Therefore, there may not be a significant increase in the cost of the goods or services. Correspondingly, another possible weak point in the introduction of VAT, which will have an adverse impact on it, is that, since the tax is to be imposed or paid at various stages and not at the last stage, it would increase the working capital requirements and interest burden on the same operation.

4. Regressive opponents and other demerits of VAT system: The opponents argue that VAT, like another consumption based-revenue source, is inherently regressive. Those least able to pay to face the highest overall burdens. Because it is believed that VAT is a broad-based tax levied on essential goods and as such must be regressive. By the same token, other demerits of VAT system are; VAT needs a formal economy where all economic units from importers to retailers document their transactions and maintain accurate records. However, in developing countries like Cameroon, the informal economy covers substantial trading which is not documented and registered. Moreover, the low literacy rate may result in poor compliance of the VAT Act and Rules. Consequently, VAT in such countries may fail to achieve its objectives. From the perspective of equity and justice, necessities and small units are exempted from VAT. Although this reduces administration costs of

\footnotetext{
${ }^{99}$ Rehana, I. (2017).,op cit.
} 
the government and the burden of compliance on the small units. But such exemption narrows the tax base, distorts the system and hence limits its success.

\section{Conclusion:-}

The main essence of this paper is to assess the buoyancy of VAT on economic development and its drifts and challenges in Cameroon. As succinctly elaborated, an increasing number of countries around the world, with Cameroon inclusive, have readily switched from the various types of consumption tax to VAT. This trend has set its footprint in almost all recent comprehensive tax reforms. With the most common form of VAT being the consumption-typed, applying the destination principle with the invoice-based credit method. In this light, a VAT on destination principle ascertains that it purely taxes domestic consumption and promotes production efficiency. Besides, the golden rule in designing an efficient VAT is that of imposing the tax on pure consumption, broadbased, and comprehensive in coverage over the whole production-distribution chain. In this connection, VAT may become a "money machine", as usually acclaimed, but only if it is simple in rate structuring and broad-based. Correspondingly, the practical advice is that the VAT rate structure be designed as simple as possible, preferably with one or - at most - two positive rates, few exemptions, and zero rating being exclusively granted to exports. Broadening base, in general sense, reduces deadweight loss and provides an opportunity for lowering the rates, and, thereby, increasing compliance. If so designed, VAT will be buoyant and efficient. Aptly, it should be noted that the zero-rating generally provides strong incentives for frauds, creating excessive burden on the tax administration, and effectively erodes the base. By the same token, the two major problems usually related to the exemption which deserve special attention are: First, exemption may induce the cascading effect and hence makes the system economically inefficient. Second, excessive exemption might tend to break up the integrity of the VAT regime and hurt its sustainability. Consequently, VAT design should minimize - to the extent possible-the number of exemptions. With this rule also being applicable to hard-to-tax sectors. ${ }^{100}$ As appreciated in New Zealand, whereby the VAT regime follows the best international tax practices by essentially limiting exemption to certain types of financial services, supply of donated goods and services by non-profit organizations, residential rental, and finished fine metals.

Conceptually and expediently, it should be noted that taxing agriculture is an acute issue. Besides, despite the tempting rationales - technical, political, and social - for sparing the sector from VAT. It is interesting to note that the sector, in principle, should be brought into the tax net. Precisely, the exemption of agriculture as seen in the case of Cameroon tends to ratchet up the exemption of agricultural inputs and thus dwarf the benefits of the zero-rating granted to exports of agricultural commodities. Likewise, the chain of exemptions leading up to the agricultural sector would be a nightmare for the administration: since it is always technically hard to distinguish agricultural inputs from non-agricultural inputs. In this regard, it should be stressed that rather than exempting agriculture and its inputs, selective outright fiscal subsidies may be provided to agriculture — if necessary - through public funds. This is because taxing agriculture should be accompanied by setting a reasonable threshold, preferably the same as the one applied in other sectors, in order to maintain a manageable number of taxpayers in the net. Apropos, for Cameroon that still exempt agriculture, for any unavoidable reason-it is advisable that it should limits the exemptions to critical and pure-for-agriculture inputs such as fertilizer and seeds only.

By the same token, small businesses are numerous and their inclusion in the tax net would lead to high collection costs, strain the already thin capacity of tax administrations, but provide low revenue potential. They should, therefore, be excluded from the VAT base, and if necessary, be subject to some type of simplified taxes such as presumptive taxation. In this regard, the threshold setting is the common procedure for excluding small businesses. Hence, it is observed that a reasonable threshold varies across the country, depending on the stage of development, capacity of tax administration, and tax culture of the country. It is, thus, sensible to set relatively high threshold level at the beginning - to accommodate the poor tax administration in the initial stage and to quench the nervousness of the public, when the tax is first announced - and to lower the threshold when administration gets improved and the public becomes familiar with the new tax regime. Likewise, the threshold should be uniform across sectors and set in terms of turnover. Besides, the related issue of voluntary registration is controversial; with some logically arguing that the provision helps relieve the tax burden on small businesses, especially small farmers. In fact, it is worth

${ }^{100}$ A survey of 37 countries with a VAT, conducted by the IMF in the late 1990s, revealsthat the majority have attempted to minimize the number of exemptions, except for selective hard-to-taxsectorssuch as education, agriculture, health, and financial services. (seeEbrill et al. (2001)., op cit. pp. 62-66). 
noting that such provision tends to strike out the very purpose of setting exemption threshold, since the tax net will become overcrowded with a large portion of small businesses.

Furthermore, the issue that VAT is inherently regressive has long been widely held. This is true, if regressivity is defined conventionally on the basis of the tax burden-to-annual gross income ratio. In fact, to reduce regressivity, it is realised that Cameroon likemany countries have attempted to incorporate in the VAT structure, multiple exemptions and/or zero rates. Cogently, these provisions are proving ineffective and yet costly in terms of revenue loss and administration complexity. Appositely, the study of regressivity in its overall context and applicability to fiscal policies including direct, indirect taxes, and public expenditures is crucial. In this connection, countries like Cameroon with VAT, need to reform their VAT with the main purpose, to strengthen income taxes, and to rationalize pro-poor public expenditures. Congruently, regressivity can be addressed more effectively with sound income taxation and government expenditures. Contrariwise, it is observed that VAT refund is a big issue in both developed and developing countries. In Cameroon, refunds get delayed - which become "hidden costs" to firms and hurt their financial cash flow. Likewise, frauds, in various shapes and forms, are widespread. Indeed, it is noted that VAT refund generally accounts for a significant share of the total VAT collection. In this regard, it is interesting to stress that in order to enhance buoyancy and efficiency within the VAT system of Cameroon, the refund issue should, therefore, be resolved with great precaution. Besides, it should be noted that the IMF is promoting an efficient model for refund processing, which combines a pre-screening "gold/silver scheme" with randomized sampling for auditing of high risk refund claimants. Likewise, a good cooperation mechanism between the tax and customs agencies would be a bolster to identify any unjustified refund claims. In addition, the tax regime should equally set transparent and severe penalty for refund fraud, specify mandatory time limit for refund processing, and impose interest on the part of refunds outstanding beyond the established mandatory time limit. Similarly, the establishment of the processing time period is critical to protect firms' cash flow and to avoid abuse by the tax administration. In sum, it is observed that for there to be success - apart from being well designed, carefully prepared the VAT system should be introduced in good timing; with country-experience studies having shown clearly that VAT does not have significant impact on inflation, though its introduction during high inflation period might tend to reduce the chance for its success. In a nutshell, the academic importance of the paper is to fathom the role tax administrations plays in ensuring the effectiveness of taxation in the informal sector. As perused, scholars have written extensively on the importance of tax administration reform among the major reforms in ensuring effective tapping into the informal sector. Hence, the paper is unique in its contribution towards enhancing the knowledge gap in existing literature by assessing the drifts and challenges of VAT, including specific resource constraints encounter in efforts towards its implementing among the informal sector in Cameroon.

\section{Recommendations}

\section{Improving Tax Revenue Collection}

1. Identifying the small enterprises: Identification of the small economic agents is a major problem facing tax authorities in low-income countries. Many factors can explain this situation. The prime factor is the complexity and costs involved in the registration procedures, which deter small enterprises from taking these steps. However, despite the development of a single identification system in Cameroon, the procedure for obtaining a business license, for instance, requires complying with many obligations at specific administrative or official agencies, like the trade registry, financial agency, and the court registry. Besides, the illiteracy among small economic agents, their low level of tax education, and the reluctance in meeting their tax obligations, are some of the reasons given for the resistance to register their businesses. In this regard, the simplification of the identification procedures, reduction of related costs and taxpayer education are among the significant measures that can likely improve the collection of the tax on the part of the small businesses.

2. Broadening the tax base and monitoring taxpayers:Given the fall in oil revenue subsequent to the collapse of oil prices, the tax effort must be increased both in terms of broadening the tax base and improving the efficiency of tax collection services. Under these conditions an increase in tax revenue must be sought through the: (i) development and implementation of an overall plan to reform the customs administration; (ii) simplification of tax procedures; (iii) rationalization of controls, and (iv) improvement of the efficiency of tax administration. All these shall readily enhance the buoyancy and efficiency of VAT.

3. Promoting fiscal compliance: To the extent that the small enterprises are not involved in the significant fraudulent activities mentioned above, their tax potential is generally weak, and the main objective of turning them into taxpayers is to develop their sense of civic responsibility. The promotion of fiscal compliance among small economic agents implies that they adhere to the tax system, a situation which can be realized only if the system is perceived as equitable. The failure to generalize the application of taxes and the existence of 
numerous exemptions and waiver regimes constitute serious obstacles to this adhesion and contribute to the expanding informal sector. Another decisive factor in the unwillingness to pay taxes is the inadequate information taxpayers receive regarding the use to which their tax contributions are put.

4. Developing a favourable business climate: The tax system and its administration are not the only obstacles to the development of the formal sector and a corresponding reduction in informal economic activities. To promote private initiative in a formal context, there must exist an attractive business climate that is favourable to investment. Thus, in addition to indispensable measures taken to ease the tax commitments of small businesses, other actions for facilitating economic activity are necessary. These measures require a concerted approach by different authorities and the development of an integrated strategy to promote the expansion of the formal sector and hence improve the cost-effectiveness of tax revenue collection.

5. Informal and illegal economic activity must be curtailed to increase tax collection: In Cameroon, the informal sector is vast and is mainly composed of small and medium enterprises (SMEs) or professionals, etc. who evade taxes. Equity considerations and the need to improve tax collection are among the many factors that favour the broadening of the tax base in order to curb underground economic activities. To guarantee a level of tax revenue consistent with the present orientations of the government budget, the priority of tax administration should remain on improving the collection of taxes from big corporations. In addition to their own contributions, these big taxpayers should promote the collection of taxes owed by their clients, employees and suppliers (through VAT, salary withholding, or instalments on profit tax payments, etc.). The enhancement of the services of major enterprises and modernization of their methods (including those concerned with research and supervision) are among the measures likely to improve the short-term performance of tax administration and increase tax revenue.

6. Further simplification of the tax system for small and medium enterprises: The regrouping of various taxes related to SMEs into a single tax (the synthetic business license) as payment in full for all tax commitments constitutes a significant achievement in terms of tax simplification for these businesses. However, the established regime still remains complex, because it retains tax bases requiring subjective tax assessment (turnover tax). In the absence of accounting statements and a dependable register, this assessment is often conducted through informal discussions between the taxpayer and agents, a method that encourages corruption. Under these conditions, a simple and transparent system must be set up. The development of tax systems adapted to SMEs also implies the simplification of other obligations, notably accounting requirements. The implementation of standards established through OHADA (Organization ofBusiness Legislation, Organisation de l'harmonisation du droit des affaires) supports simplification for the smallest enterprises, thanks to the establishment of a very simplified accounting system. In this connection, further improvement should be considered.

7. Provide adequate information and ensure taxpayer education: Responsibility for this lies with the tax administration, which must help taxpayers to meet their obligations. The tax department needs to ascertain that taxpayers receive adequate information on their obligations, the types of taxes facing them, deadlines for submitting tax returns, and payments to be made. Taxpayers also need to be informed about changes in tax legislation, have tax forms readily available, and enable easy access to information by the taxpayers.

8. Improve the services and education provided to taxpayers: This goal implies the development of information programmes (in particular for small taxpayers and new businesses), simplification of tax forms and procedures (by eliminating requests for unnecessary information), training tax agents to develop better taxpayer/tax administration relations and making available to taxpayers more efficient means for legal recourse.

9. Curbing fraudulent activities: This action requires the implementation of a strategy to crosscheck tax information. The importance and great quantity of data available for processing requires that the management of big enterprises become the primary source for information gathering. However, a more dynamic approach in terms of research must also be developed to diversify sources of information. In Cameroon, though initiatives are already being implemented to crosscheck information between the tax authorities and the customs services, with the preliminary results obtained in detecting fraudulent activities are encouraging. Moreover, these initiatives need to be generalized and crosschecking extended to available information in other services, public enterprises, and private agents (for instance, public invitations to tender, industrial consumption of water and power, use of inputs). In general, the government need to undertake measures to achieve an increase in tax revenue. To do this, it needs to revamp the improvement of administrative efficiency, law enforcement, resolution of tax disputes and exemption regimes, the fight against corruption, action to improve the sense of civic duty and correct tax fraud. Likewise, tax rules should be applied without exception.

10. Improving the management of human resources: Since the Cameroonian tax reforms were undertaken with the technical assistance of bilateral and multilateral donors during the 1980s and 1990s still remained vulnerable for 
lack of capacity building. It is, however, expediently impossible to improve tax collection without a well-trained and educated administrative staff. In this regard, there is an urgent need to consolidate efforts to build the human resource capacities of all the officials of the taxation and custom departments.

11. Tax administration need to be legally protected against political interference: An efficient tax collection system can be put in place in Cameroon by legally protecting tax administration against political interference. In this context, the tax administration must be able to fulfil its mission in an equitable and impartial manner, without political interference.

\section{Effects of Tax Distributional Impact}

The study of tax incidence consists of identifying the citizens who ultimately carry the tax burden. The theory and practice of tax incidence embrace a series of methods from the simplest to very complex that focus on the key elements of economic agents' reaction to taxes. Determining the distributional impact of taxes remains a difficult exercise because of the need to take into account their general equilibrium effects throughout the whole economy. Generally speaking, there is no ideal or single approach to analysing tax incidence. All the approaches currently in use have both advantages as well as disadvantages. Nevertheless, we recommend a tax incidence analysis for Cameroon that is based on the conventional approach, which is relatively simple and easy to apply. In addition, the assumptions on which it is based are transparent and the implications of alternative assumptions can easily be compared. Besides.the basic methodology underlying conventional models of tax incidence requires tax burdens to be allocated to income groups classified from the richest to the poorest, and by population deciles or quintiles on the basis of the assumption of who will ultimately bear the tax burden. The share of revenue collected for each tax is attributed as tax burden to each income group so as to completely exhaust the total revenue collected. To get an estimate for the entire system, the incidence of each tax is calculated separately for each income group. The resulting incidences are added up across all taxes for each income group to obtain the total tax burden for each group. More specifically, total tax burden is expressed as the average of the total tax rate, that is, the proportion of income paid in taxes by each income group. Information on total income, income sources, and spending trends is compiled from household survey data, consumer income and expenditures data, and tax revenue collected from the Ministry of Finance. The conventional approach may also use detailed data by incorporating micro simulation models of large taxpayer samples. A micro-simulation model is a computer programme comprising a tax calculator which processes data from each household, computes incomes and taxes, and then adds up the taxes thus calculated to obtain the tax burden for each income group. The conventional tax incidence analysis we are proposing for Cameroon can be supplemented with a regulatory tax incidence analysis, which involves determining who must pay which taxes, and by the analysis of the functioning of the tax collection process. 